\title{
Heme Oxygenase-1 Is Required for Angiogenic Function of Bone Marrow-Derived Progenitor Cells: Role in Therapeutic Revascularization
}

\author{
Anna Grochot-Przeczek,,2 Jerzy Kotlinowski, Magdalena Kozakowska,,2 Katarzyna Starowicz, \\ Jolanta Jagodzinska,, Anna Stachurska,, Oscar L. Volger, ${ }^{3}$ Karolina Bukowska-Strakova,,2 Urszula Florczyk, \\ Magdalena Tertil, Agnieszka Jazwa, Krzysztof Szade,,2 Jacek Stepniewski,, Agnieszka Loboda, \\ Anton J.G. Horrevoets, ${ }^{3}$ Jozef Dulak, ${ }^{1, *}$ and Alicja Jozkowicz ${ }^{1, *}$
}

\begin{abstract}
Aims: Heme oxygenase-1 (HO-1) is a cytoprotective enzyme that can be down-regulated in diabetes. Its importance for mature endothelium has been described, but its role in proangiogenic progenitors is not well known. We investigated the effect of HO-1 on the angiogenic potential of bone marrow-derived cells (BMDCs) and on blood flow recovery in ischemic muscle of diabetic mice. Results: Lack of HO-1 decreased the number of endothelial progenitor cells ( $\mathrm{Lin}^{-} \mathrm{CD} 45^{-} \mathrm{cKit}{ }^{-} \mathrm{Sca}-1^{+} \mathrm{VEGFR}-2^{+}$) in murine bone marrow, and inhibited the angiogenic potential of cultured BMDCs, affecting their survival under oxidative stress, proliferation, migration, formation of capillaries, and paracrine proangiogenic potential. Transcriptome analysis of HO-1 $1^{-1-}$ BMDCs revealed the attenuated up-regulation of proangiogenic genes in response to hypoxia. Heterozygous HO- $1^{+/-}$diabetic mice subjected to hind limb ischemia exhibited reduced local expression of vascular endothelial growth factor (VEGF), placental growth factor (PIGF), stromal cell-derived factor 1 (SDF-1), VEGFR-1, VEGFR-2, and CXCR-4. This was accompanied by impaired revascularization of ischemic muscle, despite a strong mobilization of bone marrow-derived proangiogenic progenitors $\left(\mathrm{Sca}-1^{+} \mathrm{CXCR}-4^{+}\right.$) into peripheral blood. Blood flow recovery could be rescued by local injections of conditioned media harvested from BMDCs, but not by an injection of cultured BMDCs. Innovation: This is the first report showing that HO- 1 haploinsufficiency impairs tissue revascularization in diabetes and that proangiogenic in situ response, not progenitor cell mobilization, is important for blood flow recovery. Conclusions: HO-1 is necessary for a proper proangiogenic function of BMDCs. A low level of HO-1 in hyperglycemic mice decreases restoration of perfusion in ischemic muscle, which can be rescued by a local injection of conditioned media from cultured BMDCs. Antioxid. Redox Signal. 20, 1677-1692.
\end{abstract}

\section{Introduction}

C ARDIOVASCUlar DISEASES THAT directly depend on tissue vascularity are a major medical challenge nowadays. Cell therapy with proangiogenic bone marrow-derived cells (BMDCs), in numerous reports referred to as endothelial progenitor cells (EPCs) (19), can be a promising strategy for the stimulation of blood vessel formation, particularly in patients who cannot be treated with surgical revascularization (34). Regardless of monocyte-endothelial mimicry, phenotypic heterogeneity, and still not known biological relevance of various populations [which have raised a great deal of controversy (53)], the cells derived from bone marrow or from peripheral blood were shown to participate in the formation of blood vessels in adults, mainly via paracrine signals (45). Taking into account the possible obstacles of

\footnotetext{
${ }^{1}$ Department of Medical Biotechnology, Faculty of Biochemistry, Biophysics and Biotechnology, Jagiellonian University, Krakow, Poland.

${ }^{2}$ Jagiellonian Centre for Experimental Therapeutics, Jagiellonian University, Krakow, Poland.

${ }^{3}$ Department of Molecular Cell Biology and Immunology, VU University Medical Center, Amsterdam, The Netherlands.

*These two authors contributed equally as senior authors.
} 


\section{Innovation}

Heme oxygenase-1 (HO-1) haploinsufficiency impairs angiogenic potential of bone marrow-derived cells (BMDCs), but does not affect their proliferation, migration, and survival under oxidative stress. In diabetic animals, HO-1 haploinsufficiency leads to down-regulated expression of proangiogenic genes and to impaired revascularization of ischemic tissue, despite a potent mobilization of bone marrow-derived progenitor cells into peripheral blood. This indicates that angiogenic response in situ, but not a mobilization of progenitor cells, is crucial for blood flow recovery in diabetic ischemic muscles. Application of conditioned media from BMDCs, but not the cultured cells, efficiently augments muscle reperfusion. In addition, a local injection of BMDCs does not provide an improvement in the wound-healing model, possibly due to a very fast elution of the cells.

cell therapy (safety concerns, including tumor formation, requirements for high cell numbers), the alternative cell-free strategy to induce angiogenesis by a cocktail of growth factors secreted ex vivo by the cells would also offer a therapeutic potential. However, both vasculogenic activity and release of growth factors may depend on the expression of many pro- and antiangiogenic genes in BMDCs.

An important proangiogenic gene is Hmoxl, coding for heme oxygenase-1 (HO-1), a stress-inducible cytoprotective enzyme (17). HO-1 degrades heme to carbon monoxide $(\mathrm{CO})$, ferrous ion, and biliverdin, which is subsequently reduced to bilirubin by biliverdin reductase (44). HO-1 can be induced on injury (22), augmenting the tissue regeneration (54). Proangiogenic properties of HO-1 were confirmed in various research models, both in vitro and in vivo (40). Importantly, HO-1 was shown to be an upstream and downstream mediator of vascular endothelial growth factor (VEGF) and stromal cell-derived factor 1 (SDF-1)-induced angiogenesis [reviewed in Dulak et al. (17)].

Although homozygous HO-1 deficiency is extremely rare in humans, with only two cases described so far $(55,71)$, there is a considerable variability in $\mathrm{HO}-1$ expression in human populations, which is caused by a polymorphism of Hmoxl promoter (61). Moreover, although large-scale analysis did not confirm a meaningful effect of Hmoxl promoter polymorphism on coronary artery disease or myocardial infarction (43), there are many clinical data indicating its influence on cardiovascular complications, at least in some groups of patients $(18,20)$. Thus, the presence of less active alleles was associated with an elevated rate of restenosis after balloon angioplasty (23) and with a higher incidence of coronary artery disease in type 2 diabetes (11). Moreover, among patients with peripheral artery disease (PAD), those with less active Hmoxl promoter had higher rates of myocardial infarction, percutaneous coronary interventions, and coronary bypass operations (16).

Noteworthy, the expression of HO-1 is down-regulated in some pathological conditions. We and others have demonstrated the diminished level of HO-1 in diabetic mice and rats $(14,22)$ and in leukocytes of type 2 diabetic patients $(1,50)$. This could contribute to cardiovascular complications common in diabetes, as the adenoviral Hmoxl gene transfer to diabetic mice improved angiogenesis and fastened wound healing (22). It is also known that the function of proangiogenic precursor cells is impaired in patients with cardiovascular disorders $(42,66,67)$. Therefore, an inquiry into the role of HO-1 in the activity of proangiogenic BMDCs may provide new strategies for progenitor cell modifications that are aimed at the improvement of their regenerative potency.

A few studies examining the significance of HO-1 in proangiogenic progenitors have been published to date, indicating that this enzyme plays an important role in progenitor cell mobilization, homing, and endothelialization of blood vessels (38, 57, 65, 70). However, the function of HO-1-deficient proangiogenic precursors has not been sufficiently investigated, and nothing is known about the significance of HO-1 downregulation in a more clinically relevant model, namely in proangiogenic progenitors of haplodeficient $\mathrm{HO}-1^{+/-}$mice. There are also no data concerning the potential effect of diabetes on tissue revascularization in such animals. Therefore, our aim was to investigate how HO-1 influences proangiogenic activities of BMDCs in vitro and in vivo under normoglycemic and hyperglycemic conditions, and to check whether the application of BMDCs or BMDC-derived conditioned media can improve angiogenesis in diabetic $\mathrm{HO}-1^{+/-}$mice.

\section{Results}

EPCs are less frequent in bone marrow of HO-1 deficient mice

A comparison of the bone marrow harvested from HO- $1^{-/-}$mice with that of HO- $1^{+/-}$and HO- $1^{+/+}$littermates demonstrated the decreased frequency of cells with phenotype ascribed to subpopulation of EPCs: $\mathrm{Hoe}^{+} \mathrm{Lin}^{-} \mathrm{CD} 45^{-}$ $\mathrm{cKit}^{-} \mathrm{Sca}_{-1}{ }^{+} \mathrm{VEGFR}^{+}{ }^{+}$in mice lacking HO-1 (Supplementary Fig. S1A; Supplementary Data are available online at www.liebertpub.com/ars). Such cells were very rare, constituting $0.0017 \% \pm 0.0003 \%, 0.0011 \% \pm 0.0003 \%$, and $0.0007 \% \pm 0.0002 \%$ of all nucleated cells in the bone marrow of $\mathrm{HO}-1^{+/+}, \mathrm{HO}-1^{+/-}$, and $\mathrm{HO}-1^{-/-}$individuals, respectively $(p=0.004)$. Therefore, our next experiments were performed on mononuclear BMDCs cultured under conditions that promote the development of endothelial cells (24).

Cultured BMDCs are a heterogeneous population, with $80 \%-90 \%$ of cells incorporating acetylated low-density lipoprotein (acLDL) and binding Bandeiraea simplicifolia isolectin (BS1) (Supplementary Fig. S1B, C), which are capable of forming capillary-like structures after seeding on Matrigel (Supplementary Fig. S1D). Flow cytometry phenotyping revealed that, regardless of HO-1 genotype, the BMDC populations contained a similar proportion of cultured cells expressing endothelial or hematopoietic markers, such as CD31, VEGFR-2 (KDR), Tie2, CD105, Sca-1, and CD45, with a slightly lower fraction of $\mathrm{CD}^{+} 4^{+}$subset in HO- $1^{+/-}$and HO- $1^{-/-}$cultures (Supplementary Fig. S1E). During the 9-days of culture, the population became enriched in the CD45 ${ }^{-}$cells co-expressing Sca-1 and VEGFR-2 by 400-500-fold (data not shown).

\section{HO-1 deficiency affects apoptosis, proliferation, and migration of BMDCs}

According to expectations, no $\mathrm{HO}-1$ protein was detected in $\mathrm{HO}-1^{-1-}$ BMDCs. The concentration of $\mathrm{HO}-1$ in 

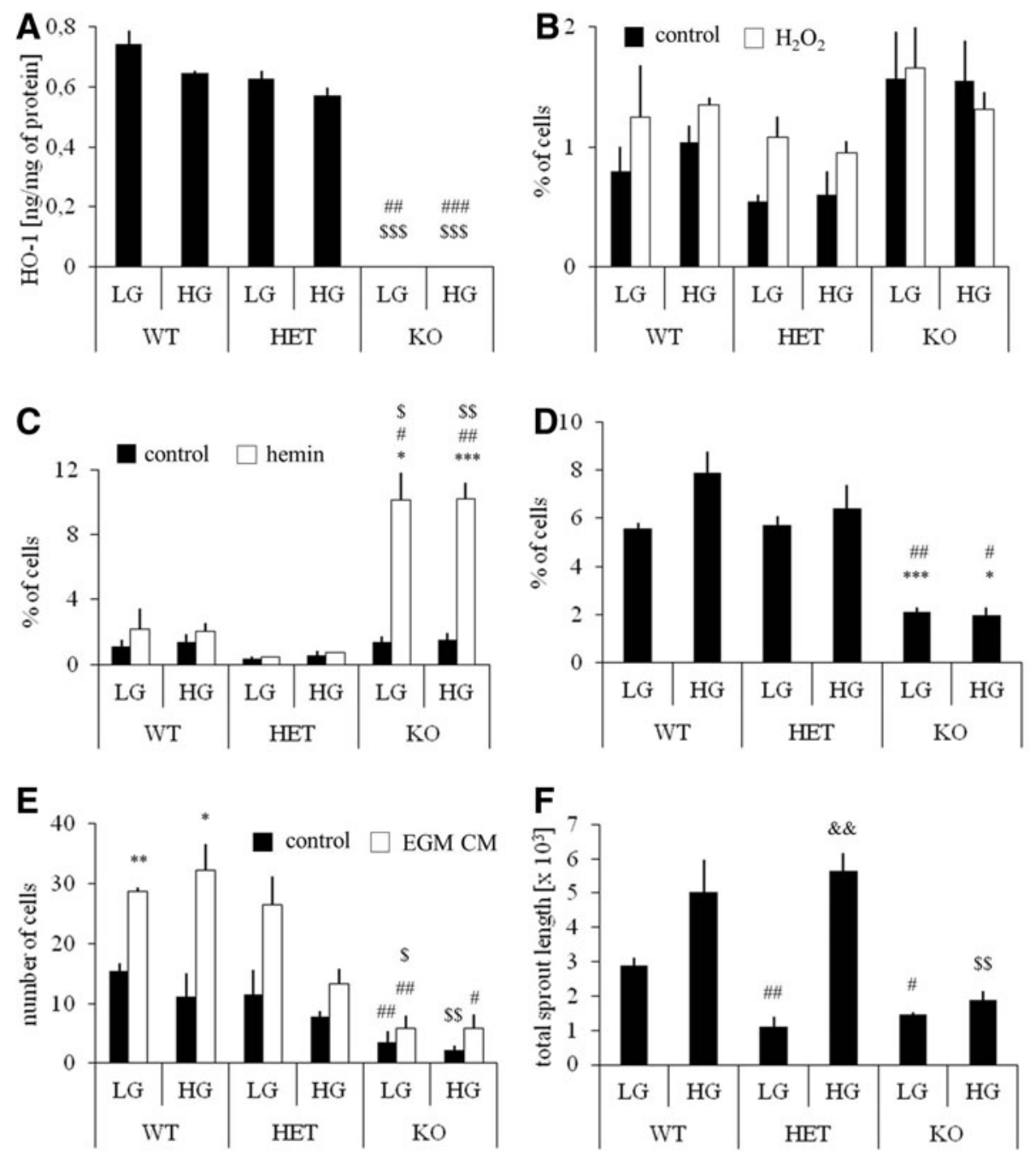

G

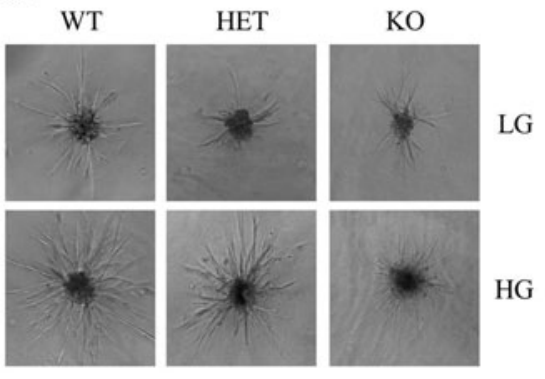

H

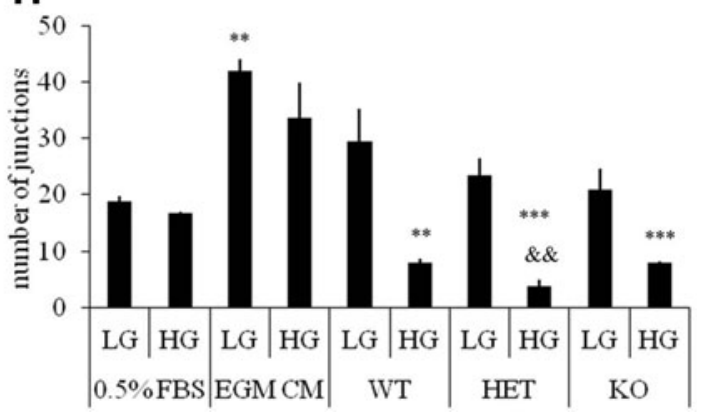

FIG. 1. Functional analysis of BMDCs isolated from WT $\left(\mathrm{HO}-1^{+/+}\right)$, HET $\left(\mathrm{HO}-1^{+/-}\right)$, and $\mathrm{KO}\left(\mathrm{HO}-1^{-/-}\right)$mice and cultured for 9 days under conditions promoting the growth of endothelial cells. Comparison of LG (5 $\mathrm{mM})$ and $\mathrm{HG}$ $(33 \mathrm{mM}$ ) conditions. Unstimulated cells served as a control. (A) HO-1 protein level in BMDCs. ELISA. (B) Cell apoptosis after exposure to $\mathrm{H}_{2} \mathrm{O}_{2}(100 \mu M, 6 \mathrm{~h})$. Hoechst/7AAD staining analyzed using flow cytometry. (C) Cell apoptosis after exposure to hemin $(50 \mu M, 6 \mathrm{~h})$. Hoechst/7AAD staining analyzed using flow cytometry. (D) Spontaneous proliferation (G2/ S phase) of BMDCs. Hoechst/pyronin Y staining analyzed using flow cytometry. (E) Spontaneous and EGM CM-induced migration of BMDCs. Transwell assay followed by crystal violet staining. $(\mathbf{F}, \mathbf{G})$ Sprouting of capillaries from the BMDC spheroids embedded in collagen gel. Morphometry. Quantitative data (F) and representative pictures (G). (H) Formation of cords by HAECs seeded on Matrigel in conditioned media harvested from BMDCs. Unconditioned medium or EGM CM medium served as negative and positive control, respectively. ${ }^{*} p<0.05, * * p<0.01, * * * p<0.001$ versus control; ${ }^{\#} p<0.05$, $\#^{\#} p<0.01,{ }^{\# \#} p<0.001$ versus WT; ${ }^{\$} p<0.05,{ }^{\$}{ }_{p}<<0.01,{ }^{\$ \$} \$<0.001$ versus $\mathrm{HET}$; ${ }^{\&} \& p<0.01$ versus $\mathrm{LG}$. WT, wild type; HET, heterozygous; KO, knockout; LG, low glucose; HG, high glucose; BMDCs, bone marrow-derived cells; HO-1, heme oxygenase-1; HAECs, human aortic endothelial cells; EGM, endothelial growth medium; CM, complete medium. 
HO- $1^{+/-}$cells was $11 \%-15 \%$ lower than in wild-type counterparts and was not modified by hyperglycemia (Fig. 1A). To evaluate the potential role of $\mathrm{HO}-1$ in the resistance of BMDCs to oxidative stress, $\mathrm{HO}-1^{+/+}, \mathrm{HO}-1^{+/-}$, and $\mathrm{HO}-1^{-l-}$ cultures were exposed for $6 \mathrm{~h}$ to $\mathrm{H}_{2} \mathrm{O}_{2}(100 \mu M)$ or hemin $(50 \mu M)$ or both under normoglycemic $(5 \mathrm{mM})$ and hyperglycemic $(33 \mathrm{mM})$ conditions. The toxic effect of $\mathrm{H}_{2} \mathrm{O}_{2}$ was weak (Fig. 1B), but treatment with hemin significantly increased the number of apoptotic cells in HO-1-deficient BMDCs (Fig. 1C), which indicates that HO-1 acts as a cytoprotective agent, especially against hemin-induced injury. Hyperglycemia did not affect cell viability (Fig. 1B, C).

Cell cycle analysis revealed that the rate of spontaneous proliferation (percentage of cells at G2 and S phases) was lower in $\mathrm{HO}-1^{-/-}$cultures, and not modified by hyperglycemia (Fig. 1D). We did not observe differences in G0 to G1 transition. HO-1-deficient cells also exhibited significantly weaker migration capacity in control starvation medium, as well as in response to endothelial growth medium (EGM) complete medium, containing a mixture of growth factors (Fig. 1E). Thus, HO-1 deficiency, but not HO-1 haploinsufficiency, impairs viability, proliferation, and migration of BMDCs, features that are important for a proper cell function within the microenvironment of injured tissue.

\section{HO-1 deficiency weakens angiogenic potential of $B M D C s$}

To evaluate the angiogenic potential of $\mathrm{HO}-1^{+/+}$, $\mathrm{HO}-1^{+/-}$, and $\mathrm{HO}-1^{-/-} \mathrm{BMDCs}$, we assessed the sprouting of capillary-like structures from the BMDC spheroids embedded in collagen gel (Fig. 1F, G). Under normoglycemic conditions, both $\mathrm{HO}-1^{+/-}$and $\mathrm{HO}-1^{-/-}$cells formed shorter capillaries than their HO- $1^{+/+}$counterparts. Surprisingly, the lengths of $\mathrm{HO}-1^{+/+}$and HO- $1^{+/-}$capillaries were increased in hyperglycemia. Such an increase was not observed in HO- $1^{-/-}$BMDCs (Fig. 1F, G).

Since proangiogenic bone marrow cells were demonstrated to facilitate blood vessel formation mainly in a paracrine manner $(45,56)$, we plated the human aortic endothelial cells (HAECs) on Matrigel in conditioned media harvested from the BMDCs (Fig. 1H). Cells cultured in unconditioned starvation medium $(0.5 \%$ fetal bovine serum $[\mathrm{FBS}])$ and unconditioned EGM complete medium served as a negative and positive control, respectively. Quantification of the number of branch points showed that conditioned media $(0.5 \%$ FBS $)$ from normoglycemic $\mathrm{HO}-1^{+/+}$BMDCs increased the formation of cord-like structures to a level which did not significantly differ from that of the positive control $(p=0.15)$. Stimulations with media from normoglycemic HO- $1^{+/-}$or HO- $1^{-/-}$BMDCs were weaker $(p=0.004$ or $p=0.015)$. Interestingly, media harvested from the BMDCs cultured in hyperglycemia, regardless of their HO-1 genotype, displayed strongly reduced paracrine proangiogenic potential (Fig. 1H).

\section{$\mathrm{HO}-1$ deficiency influences transcriptome of cultured BMDCs}

To shed light on the possible pathways that are responsible for different angiogenic potential, we compared the transcriptome of $\mathrm{HO}-1^{+/+}$and $\mathrm{HO}-1^{-/-}$BMDCs cultured for the last $24 \mathrm{~h}$ in normoxia or hypoxia (Supplementary Tables 1 and 2; all data will be provided on request). Results of Venn's analysis showed that HO-1 deficiency significantly changed the expression of 40 genes (Fig. 2A), namely 27 genes under normoxic and 18 genes under hypoxic conditions. Only five of them were regulated in the same way in both normoxia and
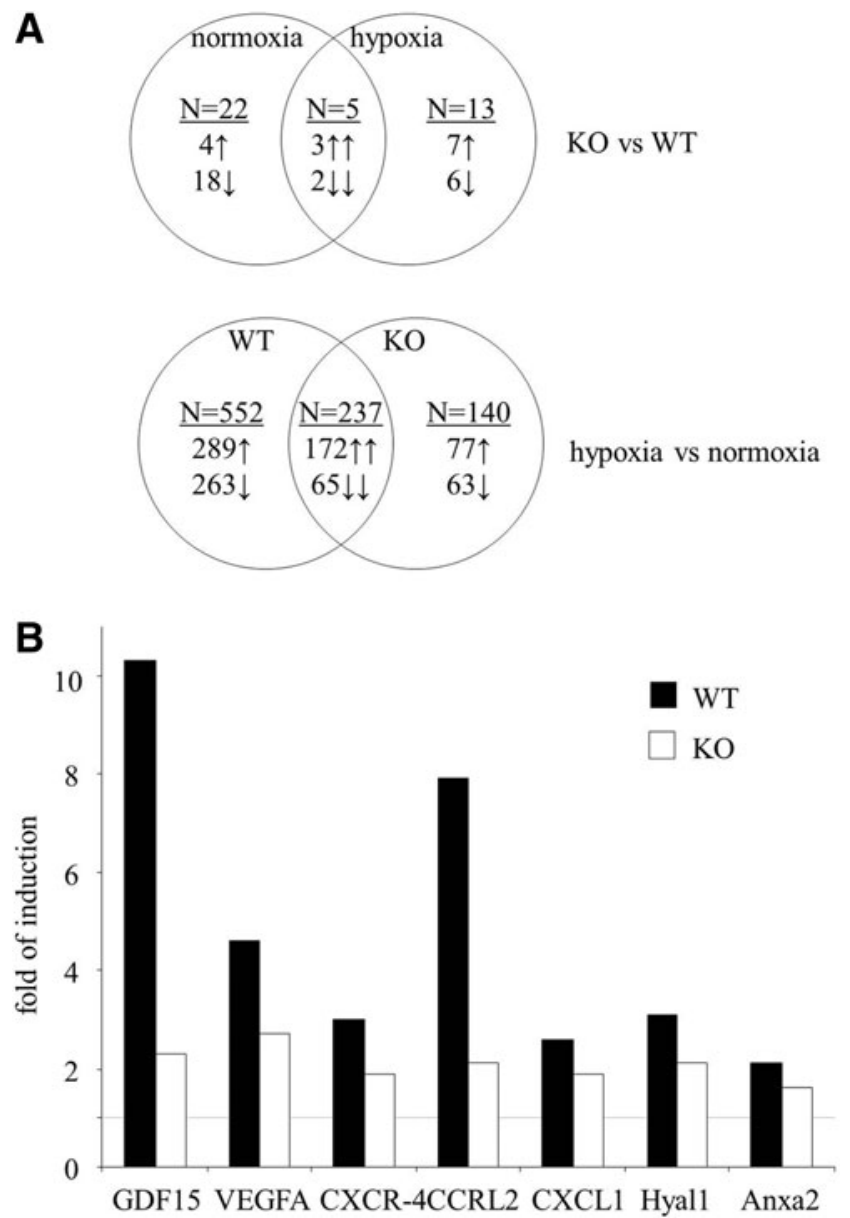

FIG. 2. Transcriptome analysis of BMDCs isolated from WT $\left(\mathrm{HO}-1^{+/+}\right)$and $\mathrm{KO}\left(\mathrm{HO}-1^{-/-}\right)$mice and cultured for 9 days under conditions promoting the growth of endothelial cells. For the previous $24 \mathrm{~h}$, cells were cultured under normoxia $\left(21 \% \mathrm{O}_{2}, 5 \% \mathrm{CO}_{2}\right)$ or hypoxia $\left(2 \% \mathrm{O}_{2}\right.$, $5 \% \mathrm{CO}_{2}$ ). Microarray analysis. (A) Venn's diagram summarizing the effect of HO-1 deficiency and hypoxia on BMDC transcriptome. The upper part demonstrates the number of genes whose expression was changed in either normoxic or hypoxic conditions due to $\mathrm{HO}-1$ deletion (22 genes are changed: 4 up-regulated and 18 down-regulated in $\mathrm{KO}$ BMDCs in normoxic conditions. Thirteen genes are changed: 7 up-regulated and 6 down-regulated in KO BMDCs in hypoxic conditions. Five genes are changed: three up-regulated and two down-regulated in KO BMDCs regardless of oxygen concentration). Bottom part shows the number of genes whose expression was changed in either WT or KO cells in response to hypoxia (552 genes are changed: 289 up-regulated and 263 down-regulated in WT BMDCs in response to hypoxia. One hundred forty genes are changed: 77 up-regulated and 63 down-regulated in KO BMDCs in response to hypoxia. Two hundred thirty-seven genes are changed: 172 up-regulated and 65 down-regulated in both genotypes in response to hypoxia). (B) Examples of hypoxia-mediated inductions of proangiogenic genes in WT and KO BMDCs. Dashed line indicates the control level of gene expression under normoxic conditions. 
hypoxia: kininogen-1 (Kngl) and V-set and immunoglobulin containing-4 (Vsig4) were down-regulated, while acetyltransferase like-1 (Aytl1), WNT1-inducible signaling pathway protein-1 (Wispl), and solute carrier family-40 member-1 (Slc40al) were up-regulated. Thus, in most cases, the effect of HO-1 deficiency was dependent on the oxygen level.

$\mathrm{HO}-1^{+/+}$and $\mathrm{HO}-1^{-/-}$BMDCs differentially expressed some genes regulating angiogenesis, inflammatory reaction, proliferation, and apoptosis. Lack of HO-1 was associated with down-regulation of several proangiogenic genes, such as cyclin-dependent kinase-5 (Cdk5), activating protein-2 (AP2), R-spondin-2 homolog (Rspo2), matrix metalloproteinase11 (MMP-11), metallotionein-1, Sca-1 (lymphocyte antigen-6 complex, locus-A [Ly6a]), lymphocyte antigen-6 complex, locus-C1 $(L y 6 c)$, or ceruloplasmin, and up-regulation of Wisp1, which can exert antiangiogenic effects. In addition, among the 40 genes influenced by HO-1 deficiency, there were 9 genes of the WNT pathway, 5 genes associated with iron metabolism, and genes regulating adipogenesis (12) or osteogenesis (2) (Supplementary Table 1).

In the next step of transcriptome analysis, we checked the effect of hypoxia in $\mathrm{HO}-1^{+7+}$ and $\mathrm{HO}-1^{-1-}$ BMDCs. According to Venn's diagram, 929 genes are differently expressed under normoxia and hypoxia in $\mathrm{HO}-1^{+/+}, \mathrm{HO}-1^{-/-}$, or in both cell types (Fig. 2A and Supplementary Table 2). The majority of them (552 genes) changed under hypoxic conditions only in $\mathrm{HO}-1^{+/+}$BMDCs, while 140 changed only in HO- $1^{-/-}$cells. Thus, HO-1 deficiency modifies the response to hypoxia, attenuating the hypoxic induction of several proangiogenic genes, including growth differentiation factor-15 (GDF-15), VEGF, chemokine receptor-like 2 (CCRL2), chemokine receptor-4 (CXCR-4), chemokine ligand-1 (CXCL-1), hialuronidase-1 (Hyal1), or annexin-A2 (Anxa2) (Fig. 2B and Supplementary Table 2).

\section{$B M D C$ transplantation improves tissue regeneration neither in cutaneous wound nor in hind limb ischemia models}

To investigate the influence of HO-1 deficiency on the regenerative potency of BMDCs, we used two in vivo models. In the first one, either $\mathrm{HO}-1^{+/+}$or $\mathrm{HO}-1^{-/-}$BMDCs were injected intradermally around the cutaneous wounds in $\mathrm{HO}-1^{-1-}$ mice, in which the wound-healing process was previously shown to be impaired (22). We observed much more HO- $1^{+/+}$PKH67-positive BMDCs within the wounds in comparison to $\mathrm{HO}-1^{-/-}$cells at day 14 post-injury (Fig. 3A, B). However, there was no statistical difference in the time course of wound closure between all investigated groups, including the PBS-treated animals (Fig. 3C).

To determine the real proportion of transplanted cells surviving after an intradermal injection, we performed an
FIG. 3. Effect of BMDC transplantation on WT $\left(\mathrm{HO}-1^{+/+}\right)$or $\mathrm{KO}\left(\mathrm{HO}-1^{-/-}\right)$mice. $(\mathrm{A}, \mathrm{B})$ Number of WT and KO BMDCs 14 days after transplantation (900,000 cells/mouse) to the wound bed of KO mice. Quantitative data (A) and representative pictures (B). (C) Wound closure in $\mathrm{KO}$ mice injected with PBS (control), WT BMDCs, and KO BMDCs (900,000 cells/mouse), presented as a percentage of wound surface at day 0. Morphometry. (D) Number of WT and KO male BMDCs after transplantation (200,000 cells/mouse) into the skin of female WT mice. Quantitative data. (E) Blood flow in ischemic muscle in WT and $\mathrm{KO}$ mice injected intravenously with PBS (control), WT BMDCs, or KO BMDCs (500,000 cells/mouse). Laser Doppler analysis. $* p<0.05$ KO versus WT, ${ }_{p}<0.05$ versus day 0 . To see this illustration in color, the reader is referred to the web version of this article at www.liebertpub.com/ars
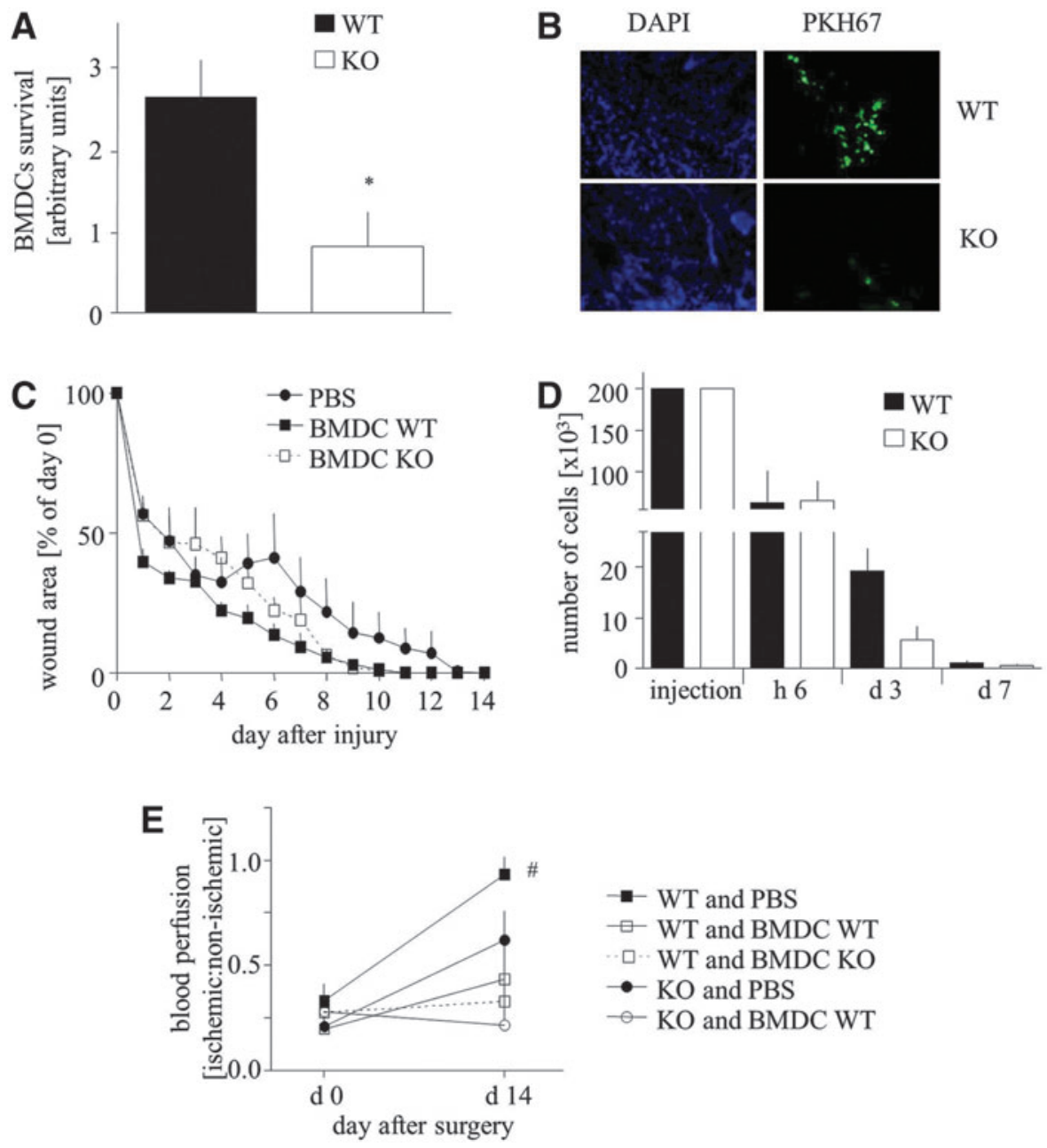
additional analysis using sex-mismatched transplantation (male BMDCs transplanted to female skin), followed by quantitative polymerase chain reaction (PCR) to measure the level of male sry gene. Number of the surviving cells was calculated using a standard curve (Supplementary Fig. S2). The obtained results revealed that about $70 \%$ of BMDCs were eluted from the tissue within $6 \mathrm{~h}$ after an injection, regardless of their genotype (Fig. 3D). Next, $70 \%$ and $90 \%$ of HO- $1^{+/+}$and HO- $1^{-l-}$ cells, respectively, did not survive for subsequent 3 days. Importantly, BMDC endurance on day 3 tended to be weakened in case of $\mathrm{HO}-1^{-/-}$cells $(p=0.068)$. Thus, of the 200,000 cells injected, only about $1100 \mathrm{HO}-1^{+/+}$BMDCs and $600 \mathrm{HO}-1^{-/-}$BMDCs were still present in the skin 7 days after the injection (Fig. 3D), and 1 week later their number was less than 50, preventing catching the specific PCR signal.

In another model, mice underwent femoral artery ligation and were subsequently (next day) intravenously injected with PBS, HO- $1^{+/+}$, or HO- $1^{-/-}$BMDCs. Unexpectedly, in wildtype mice, the adoptive transfer of BMDCs impaired tissue reperfusion, regardless of cell genotype (Fig. 3E). Measurements performed at day 14 also revealed the impaired blood flow recovery in $\mathrm{HO}-1^{-1-}$ animals in comparison to wildtype counterparts. Again, the adoptive transfer of $\mathrm{HO}-1^{+/+}$ BMDCs did not improve the reperfusion but, instead, appeared to result in a disadvantageous effect (Fig. 3E). Quantitative PCR analysis of Sry level after a sex-mismatched intravenous injection of 500,000 cells was not sensitive enough to detect the injected cells in the injured muscle, either $6 \mathrm{~h}$ or at the later time points, which indicates that the homing of injected BMDCs to the ischemic tissue was weak (data not shown).

\section{Hyperglycemia affects expression of proangiogenic genes in $\mathrm{HO}-1^{+/-}$mice}

In the next set of experiments, we investigated whether a decrease in HO-1 expression may influence revascularization of ischemic tissue in diabetes. Since HO-1 promoter polymorphism in human populations leads to a strong variability in HO-1 expression and insufficient induction of HO-1 can be associated with cardiovascular complications in diabetic patients (11), we decided to perform the study using the more clinically relevant model of $\mathrm{HO}-1^{+/-}$instead of $\mathrm{HO}-1^{-/-}$ mice.

Hyperglycemia in mice was induced by injections of streptozotocin (STZ), with 100\% efficiency of the procedure in both genotypes. Nevertheless, we observed a significantly higher mortality of $\mathrm{HO}-1^{+/-}$mice in comparison to $\mathrm{HO}-1^{+/+}$ counterparts $(42.7 \%$ vs. $16.6 \%$, respectively; $p<0.05) 4$ weeks after STZ dosing. Interestingly, there were obvious differences in the expression of proangiogenic genes in the caput gastrocnemius muscle between the wild-type and heterozygous animals (Fig. 4A-F). Namely, placental growth
A
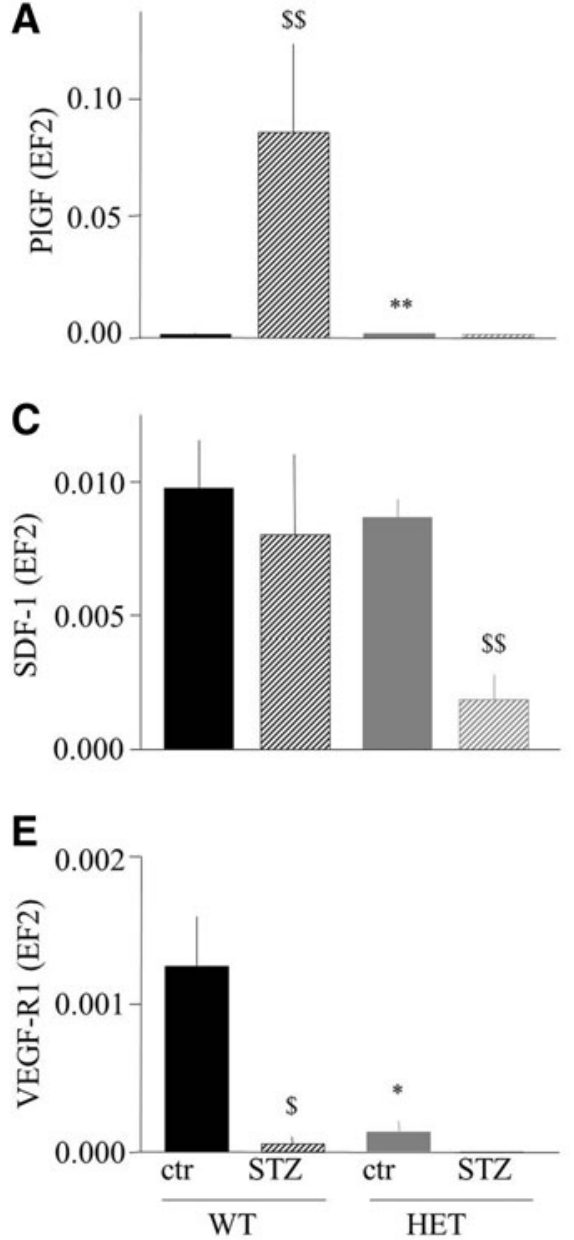

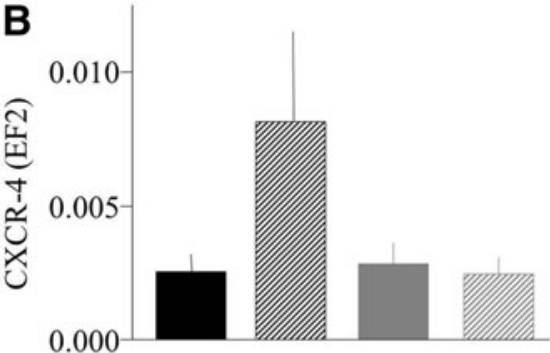

D
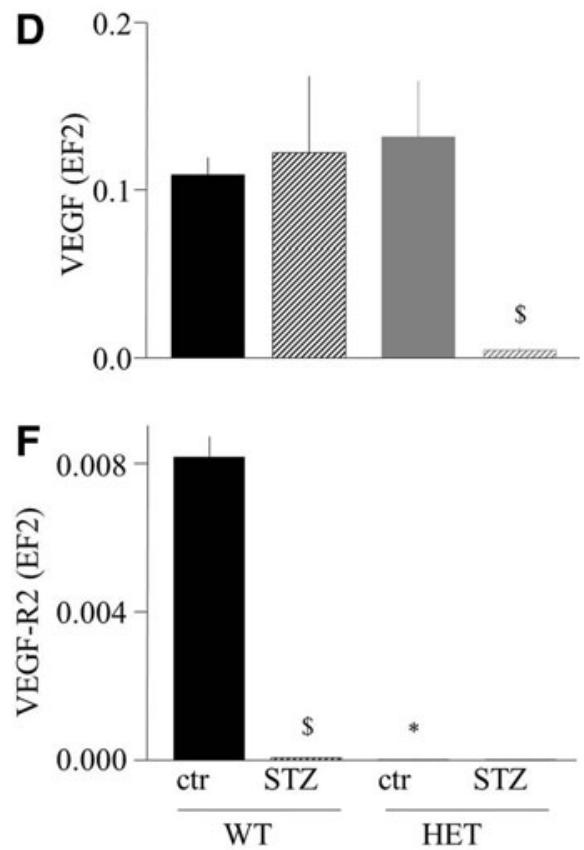

FIG. 4. Expression of proangiogenic genes in caput gastrocnemius muscle of normoglycemic (control, ctr) and hyperglycemic (STZ) WT (HO-1 ${ }^{+/+}$) and HET $\left(\mathrm{HO}^{+/-}\right)^{+/}$mice. Quantitative mRNA analysis using qRT-PCR, EF2 constitutive gene served as an internal control. (A) PlGF. (B) CXCR-4. (C) SDF-1. (D) VEGF. (E) VEGFR-1. (F) VEGFR-2. $* p<0.05, * * p<0.01$ WT versus HET; $\$ p<0.05, \quad \$ p<0.01$ versus control. PlGF, placental growth factor; SDF-1, stromal cell-derived factor 1; STZ, streptozotocin; VEGF, vascular endothelial growth factor; qRT-PCR, quantitative reverse transcription-polymerase chain reaction. 
factor (PlGF) (Fig. 4A) and CXCR-4, the SDF-1 receptor (Fig. 4B), were up-regulated by STZ-induced hyperglycemia (in case of PlGF, significantly; in case of CXCR-4, it was a tendency, $p=0.15)$ in the $\mathrm{HO}-1^{+/+}$but not in the HO- $1^{+/-}$ individuals. On the other hand, the expression of SDF-1 (Fig. 4C) and VEGF (Fig. 4D) was lower in hyperglycemic $\mathrm{HO}-1^{+/-}$individuals in comparison to control $\mathrm{HO}-1^{+/-}$ mice or to both $\mathrm{HO}-1^{+/+}$groups, whereas the PlGF and VEGF receptors (VEGF-R1 and VEGF-R2) were strongly down-regulated in hyperglycemic groups and in normoglycemic $\mathrm{HO}-1^{+/-}$mice (Fig. 4E, F). Thus, gene expression analysis may suggest that tissue revascularization might be impaired in hyperglycemic HO-1 haplodeficient individuals.

Blood flow recovery is impaired in hyperglycemic $\mathrm{HO}-1^{+/-}$mice in spite of progenitor cell mobilization

We investigated the mobilization of progenitor cells (Sca$1^{+} \mathrm{CXCR}-4^{+}$) into peripheral blood in response to femoral artery ligation at day 1,2, and 3 after surgery. Flow cytometry analysis showed that in wild-type mice, either normogly- cemic or hyperglycemic induction of hind limb ischemia did not mobilize Sca $-1^{+} \mathrm{CXCR}-4^{+}$cells. In contrast, in $\mathrm{HO}-1^{+/-}$ counterparts, the same procedure resulted in a significant increase in circulating progenitor cells, especially in hyperglycemic individuals, with a peak of mobilization at $24 \mathrm{~h}$ after surgery (Fig. 5A). Accordingly, SDF-1 gradient between ischemic muscle and bone marrow, measured at mRNA level, was the highest in hyperglycemic $\mathrm{HO}-1^{+/-}$mice (Fig. 5B).

SDF-1 gradient did not correlate with the expression of HO- 1 in the caput gatrocnemius muscle. Concentration of $\mathrm{HO}-1$ protein in the healthy muscle of $\mathrm{HO}-1^{+/-}$mice was lower roughly by $50 \%$ in comparison to that of $\mathrm{HO}-1^{+1+}$ counterpart, and in both groups it was decreased after STZ treatment (Fig. 5C). Induction of ischemia led to a gradual increase in HO-1 protein levels, but this effect was significant only in the hyperglycemic $\mathrm{HO}-1^{+/-}$mice. Despite this upregulation, concentration of $\mathrm{HO}-1$ protein in the muscle remained lower in the $\mathrm{HO}-1^{+/-}$mice in comparison to the HO- $1^{+/+}$mice (Fig. 5C).

Thus, HO-1 haploinsufficiency in hyperglycemic mice diminishes the expression of proangiogenic genes (Fig. 4); on
FIG. 5. Effect of HO-1 haploinsufficiency on progenitor cell mobilization and blood flow recovery in mice subjected to hind limb ischemia. Femoral artery ligation was performed in normoglycemic (control, ctr) and hyperglycemic (STZ) WT $\left(\mathrm{HO}-1^{+\%+}\right)$ and $\mathrm{HET}$ $\left(\mathrm{HO}-1^{+/-}\right)$mice. (A) Fraction of progenitor cells (Sca$\left.1^{+} \mathrm{CXCR}-4^{+}\right)$in peripheral blood before operation or 1 , 2 , and 3 days after the induction of ischemia. Flow cytometry phenotyping. (B) SDF-1 gradient between ischemic caput gastrocnemius muscle and bone marrow measured at mRNA level. qRT-PCR. EF2 constitutive gene served as an internal control. (C) HO-1 protein expression in caput gastrocnemius muscle. (D, E) Blood flow recovery in ischemic muscle. Laser Doppler analysis. Quantitative data (D) and representative scans (E). $* p<0.05, \quad * * p<0.01, \quad$ and $* * * p<0.001$ HET versus WT; $\quad{ }^{\#} p<0.05, \quad{ }^{\# \#} p<0.01$, and $\# \# p<0.001$ versus day 0 ; and ${ }^{\$} p<0.05$ versus normoglycemic counterparts. To see this illustration in color, the reader is referred to the web version of this article at www.liebertpub.com/ars
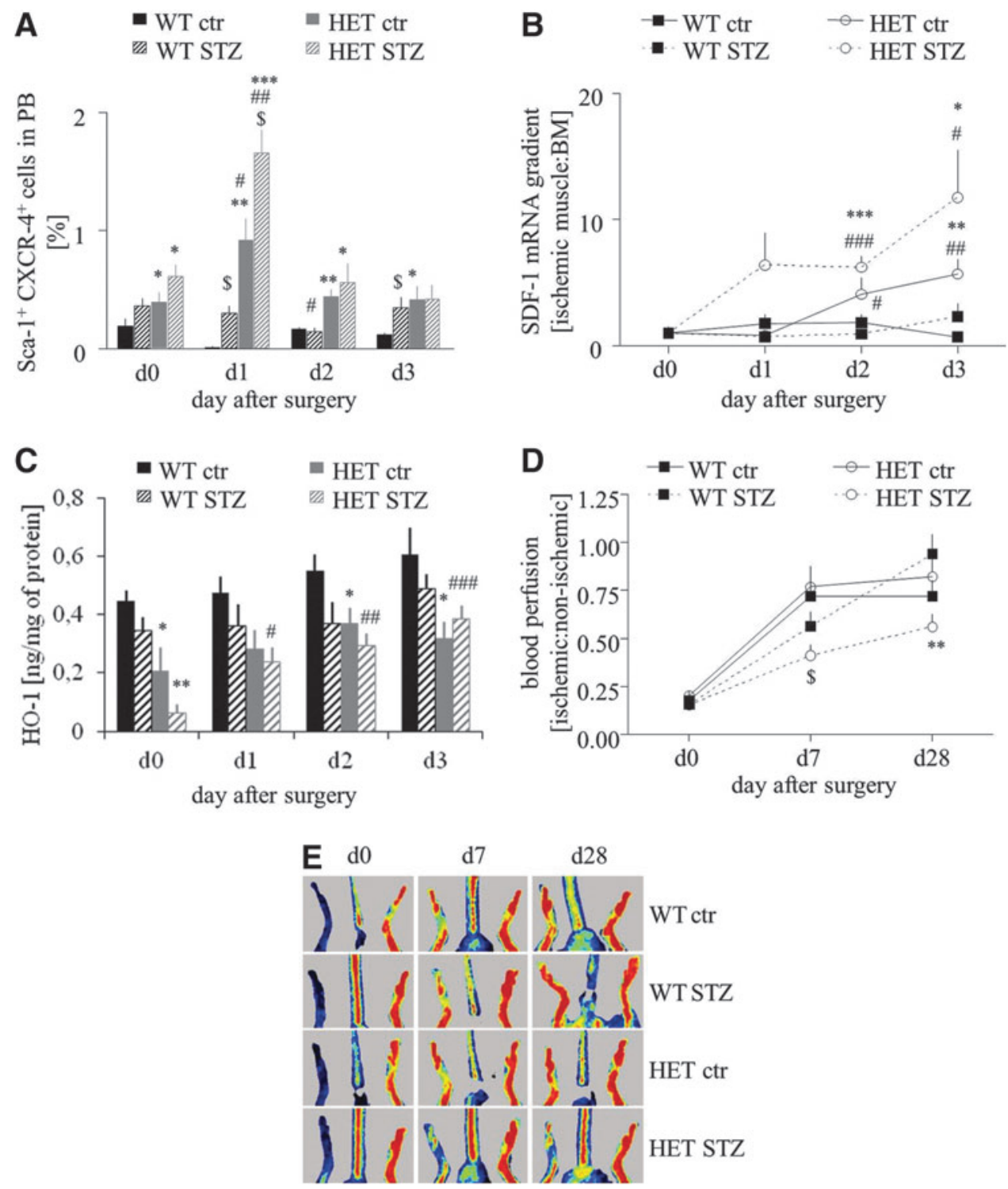
the other hand, it leads to the strongest mobilization of progenitor cells into peripheral blood in response to ischemia (Fig. 5A). To check which of these two processes is more significant in tissue regeneration, we investigated blood flow recovery in $\mathrm{HO}-1^{+/-}$and $\mathrm{HO}-1^{+/+}$mice. Laser Doppler scanning did not reveal any difference between perfusion in normoglycemic HO-1 heterozygous and normoglycemic HO-1 wild-type animals at any time point. However, reperfusion was significantly impaired at day 28 post-surgery in hyperglycemic $\mathrm{HO}-1^{+/-}$animals when compared with hyperglycemic HO- $1^{+/+}$(Fig. 5D, E). Collectively, these results show that blood flow recovery is impaired in hyperglycemic $\mathrm{HO}-1^{+/-}$despite progenitor cell mobilization.

Cell-free strategy for therapeutic angiogenesis is an effective way to improve blood flow recovery

Since survival rate of locally injected cells was low (Fig. 3D) and an intravenous injection of BMDCs did not improve blood flow recovery and even resulted in deleterious effects (Fig. 3E), we used a cell-free strategy for therapeutic angiogenesis in a model of hind limb ischemia. For this purpose, hyperglycemic $\mathrm{HO}-1^{+/-}$mice, in which tissue revascularization is impaired (Fig. 5D, E), were subjected to angiogenic therapy utilizing conditioned EBM-2 media (with $0.5 \% \mathrm{FBS}$ ) either from $\mathrm{HO}-1^{+/+} \mathrm{BMDCs}$ or from $\mathrm{HO}-1^{-1-}$ BMDCs. Unconditioned EBM-2 medium with $0.5 \%$ FBS was used as a control.

Media injections were administered for 3 consecutive days after femoral artery ligation. Blood flow increased in ischemic limbs on day 3 post-surgery in animals treated with conditioned media in comparison to control group. This effect was prominent on day 7 (Fig. 6A, B). Although the improvement reached higher values in animals injected with media harvested from $\mathrm{HO}-1^{+/+}$than $\mathrm{HO}-1^{-/-}$BMDCs, these differences were not statistically significant. Interestingly, the number of necrotic incidences (appearance of necrotic toes) was not fully parallel to the measured blood flow. Namely, 3 days after surgery, the number of necrotic toes significantly increased in control group $(p<0.001)$, showed a tendency to increase in animals injected with media from HO- $1^{-I-}$ BMDCs $(p=0.051)$, and did not significantly increase in counterparts injected with $\mathrm{HO}-1^{+/+}$BMDCderived media $(p=0.485)$. On day 7 , the increase in necrotic events became significant in all groups; however, the animals injected with media from $\mathrm{HO}-1^{-1-}$ BMDCs were very similar to those injected with control media, whereas there was a tendency for weaker increase in animals treated with media from HO- $1^{+/+}$BMDCs $(p=0.086)$.

Analysis of gene expression revealed the tendency or significant up-regulation of VEGF, PIGF, and SDF-1 mRNAs in particular groups at day 7 after surgery (Fig. 7A-C). Interestingly, the HO-1 expression also was elevated in all investigated groups, which was shown at both mRNA (Fig. 7D) and protein (Fig. 7E) levels. Immunohistochemical staining for CD31 showed that the number of capillaries was significantly augmented in ischemic tissue in animals injected with HO- $1^{+/+}$BMDC-conditioned media (Fig. 7F).

\section{Discussion}

Exploitation of autologous patients' cells, subjected to ex vivo genetic modification to improve their regenerative
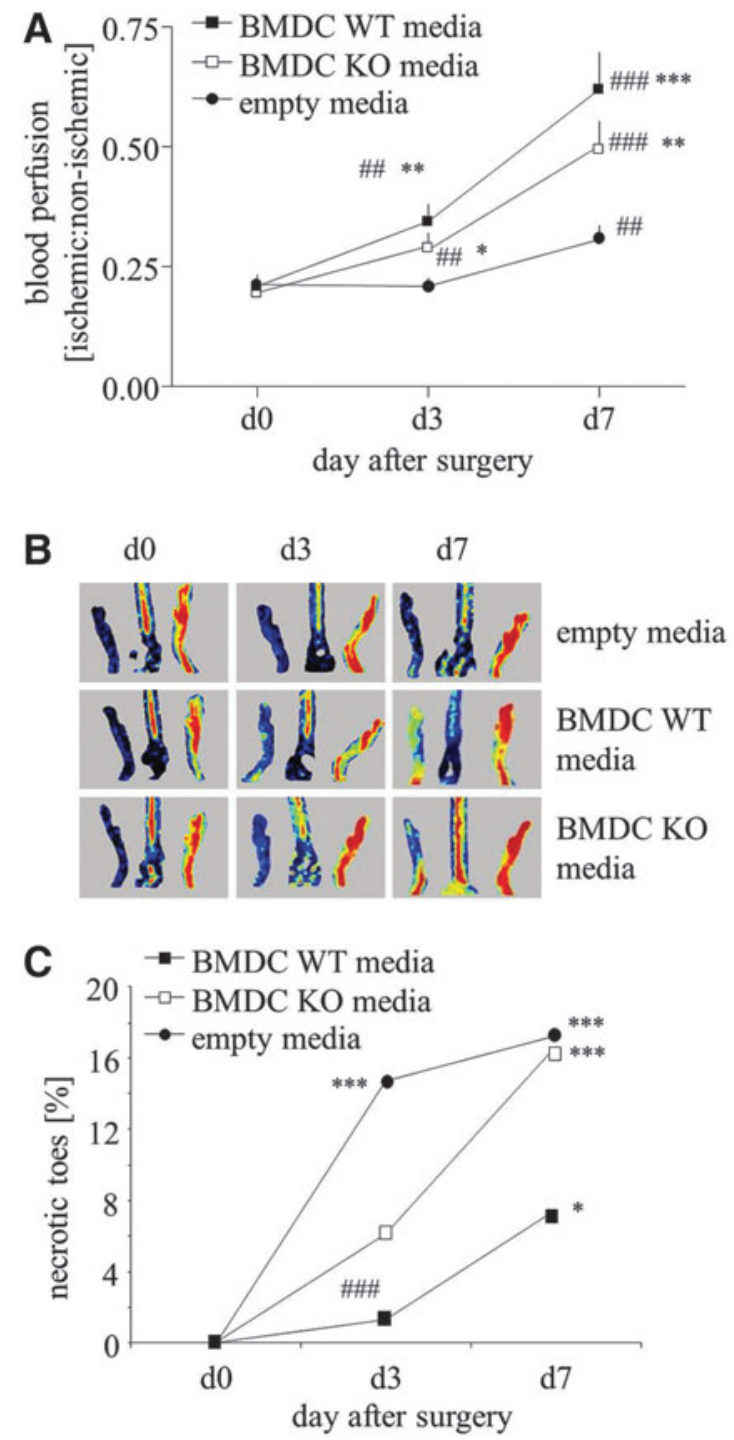

FIG. 6. Effect of conditioned media harvested from WT $\left(\mathrm{HO}-1^{+/+}\right)$or KO (HO-1 $\left.{ }^{-/-}\right)$BMDCs on blood flow recovery in hyperglycemic HET $\left(\mathrm{HO}^{-1} \mathbf{1}^{+-}\right)$muscle. Media $(30 \mu \mathrm{l}$ in total) were injected into three sites of ischemic caput gastrocnemius muscle of mice subjected to femoral artery ligation. Injections were performed immediately after surgery (day 0 ), on day 1 , and on day 2 . Unconditioned media served as a control. (A, B) Blood flow recovery in ischemic muscle. Laser Doppler analysis. Quantitative data (A) and representative scans (B). (C) Percentage of necrotic toes. $* p<0.05$, $* * p<0.01$, and $* * * p<0.001$ versus control; ${ }^{\#} p<0.05,{ }^{*} p<0.01$, and \#\#\# $p<0.001$ versus day 0 . To see this illustration in color, the reader is referred to the web version of this article at www.liebertpub.com/ars

potency, could be a promising strategy for the treatment of PAD. Hmoxl gene, encoding cytoprotective and proangiogenic HO-1 enzyme (17), is one of candidates considered for such therapy.

We found that the lack of HO-1 decreases the number of EPCs in murine bone marrow, and strongly inhibits the proangiogenic potential of cultured BMDCs, affecting their survival under oxidative stress, proliferation, migration, 
FIG. 7. Effect of conditioned media harvested from WT $\left(\mathrm{HO}-1^{+/+}\right)$or $\mathrm{KO}$ (HO-1 ${ }^{-/-}$) BMDCs on gene expression and capillary number in hyperglycemic HET (HO-1 ${ }^{+\%}$ ) muscle. Media $(30 \mu \mathrm{l}$ in total) were injected into three sites of ischemic caput gastrocnemi$u s$ muscle of mice subjected to femoral artery ligation. Injections were performed immediately after surgery (day 0 ), on day 1 , and on day 2. (A-D) Expression of proangiogenic genes on day 7 after surgery. Quantitative mRNA analysis using qRTPCR. EF2 constitutive gene served as an internal control. (A) VEGF. (B) PlGF. (C) SDF-1. (D) HO-1. (E) HO-1 protein expression in caput gastrocnemius muscle. (F) Number of capillaries in control and ischemic muscle analyzed on day 7 after surgery. CD31 immunohistochemical staining analyzed using a fluorescence microscope. $* p<0.05$ versus control; ${ }^{\#}<<0.05,{ }^{\#} p<0.01$, and \#\#\#, $p<0.001$ versus healthy muscle. To see this illustration in color, the reader is referred to the web version of this article at www.liebertpub .com/ars
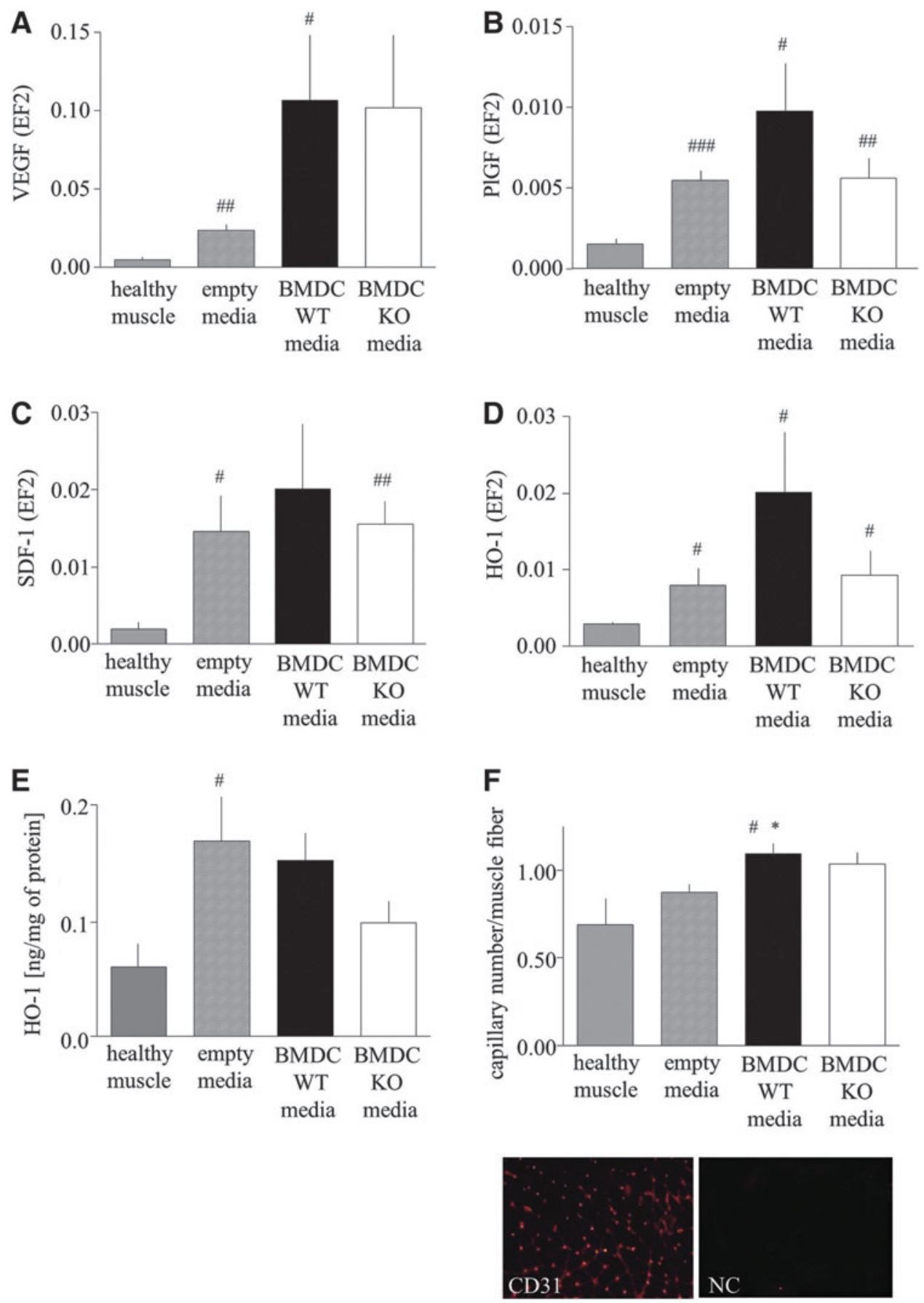

formation of capillary-like structures, and release of paracrine growth factors, although the influence on paracrine functions seems to be weaker than that on direct vasculogenic activities. These effects are accompanied by changes in BMDC transcriptome profile, including the reduced upregulation of several proangiogenic genes in response to hypoxia. In addition, STZ-treated diabetic $\mathrm{HO}-1^{+/-}$mice exhibit lower expression of proagiogenic genes and impaired revascularization of ischemic muscles subjected to hind limb ischemia, in spite of strong mobilization of bone marrowderived proangiogenic progenitors into peripheral blood.

We also observed that the administration of STZ causes a much higher mortality of HO- $1^{+/-}$animals in comparison to their HO- $1^{+/+}$counterparts, with a concomitant down-regulation of HO-1. Since STZ is nephro- and hepatotoxic (36), and HO-1 was shown to be protective in these organs $(48,73)$, a low level of hyperglycemic HO-1 protein may explain the increased mortality of $\mathrm{HO}-1^{+/-}$individuals. Such decreased expression of HO-1 was also found in $\mathrm{db} / \mathrm{db}$ mice (22) and in the Goto-Kakizaki rats (46), as well as in type 2 diabetes patients $(1,8,12,50)$.

Lack of HO-1 attenuates revascularization in $\mathrm{HO}-1^{-1-}$ mice (26). Here, we demonstrated that haploinsufficiency of HO-1 does not influence the recovery of blood flow after hind limb ischemia in normoglycemic animals, but impairs it in hyperglycemic individuals. This corresponds to a clinical 
situation, as there is no association of PAD occurrence with Hmoxl promoter polymorphism (58), but less active Hmoxl alleles can increase the risk of coronary adverse events in diabetic patients (16). Noteworthy, the expression of HO-1 protein was lower by $\sim 40 \%$ in humans with less active variants of promoter ( $\geq 29$ GT repeats) in comparison to those with more active ( $\leq 23 \mathrm{GTs}$ ) alleles (16). This indicates that HO-1 haploinsufficiency in mice is relevant to the diversity of HO-1 expression in the human population.

Blood flow recovery in our hyperglycemic wild-type mice was very effective. This might be astonishing, as some reports show a hyperglycemia-induced impairment in revascularization (9). However, the restoration of perfusion in STZ-treated mice may depend on the interval between diabetes induction and artery ligation (52). When surgery is done 4 weeks after STZ treatment, diabetic mice regenerate as effectively as normoglycemic animals (52), which has also been confirmed by the present study. Differently, reperfusion in hyperglycemic $\mathrm{HO}-1^{+/-}$mice was both delayed and diminished at the endpoint by $40 \%$ in comparison to $\mathrm{HO}-1^{+/+}$ animals. To our knowledge, this is the first report on STZtreated HO-1 heterozygous mice. Earlier, Liu et al. showed that in the wild-type hyperglycemic animals the myocardial expression of HO-1 was strongly up-regulated in response to ischemia-reperfusion injury, whereas the lack of HO-1 exacerbates tissue damage (39). An insufficient level of HO-1 might be one of the possible reasons of impaired revascularization in hyperglycemic $\mathrm{HO}-1^{+/-}$animals.

It has been shown that the transfer of HO-1 transgene into ischemic muscle diminishes cell apoptosis, induces angiogenesis, enhances muscle perfusion, and limits autoamputations in mice and rats $(6,26,60)$. In diabetic $\mathrm{db} / \mathrm{db}$ mice, adenoviral delivery of HO-1 cDNA facilitates neovascularization and improves wound healing (22). Likewise, intracoronary transfer of HO-1 overexpressing bone marrow stromal cells increases expression of VEGF as well as capillary and arteriole density in a porcine model of myocardial ischemia reperfusion (27). Moreover, simultaneous transplantation of VEGF and HO-1 overexpressing cells facilitated blood flow recovery and decreased the number of necrotic incidents (41). These data indicate that in vivo revascularization is dependent on HO-1.

Impaired blood flow recovery in $\mathrm{HO}-1^{+/-}$hyperglycemic mice corresponds to down-regulation of proangiogenic genes in caput gastrocnemius muscle. Only in these animals, the expressions of all genes tested, namely PlGF, VEGF, SDF-1, VEGFR-1, VEGFR-2, and CXCR-4, are strongly decreased. In hyperglycemic $\mathrm{HO}-1^{+/+}$and normoglycemic $\mathrm{HO}-1^{+/-}$ animals, which regenerate efficiently, there is a low expression of VEGFR-2, but VEGF can also bind to neuropilin-1 and influence endothelial cells independently of VEGFR-2 signaling (3).

Many studies have described the beneficial effects of proangiogenic progenitors in tissue vascularization and regeneration [reviewed in Asahara et al. (2)]. We investigated the progenitor cell mobilization into peripheral blood in response to femoral artery ligation. Taking into account the monocytic origin of EPCs and endothelial-monocyte mimicry, we focused on $\mathrm{Sca}-1^{+} \mathrm{CXCR}-4^{+}$cells, especially because such widely defined populations (e.g., MNCs, CD34 ${ }^{+}$ cells, CD $34^{+} \mathrm{CD}_{133}{ }^{+}$cells), enriched in EPCs, were used in all clinical trials for the treatment of $\operatorname{PAD}(30,33,62)$.
Mobilization of Sca- $1^{+} \mathrm{CXCR}-4^{+}$cells occurs only in $\mathrm{HO}-1^{+/-}$ mice, and hyperglycemia enhances this process. However, blood flow recovery is impaired in hyperglycemic individuals. Therefore, we suppose that the mobilized cells are dysfunctional and do not contribute to tissue regeneration. They can be unable to home to injured muscle or can have reduced regenerative potency, and their release into circulation can only be a marker of stress reaction. Accordingly, Sca $-1^{+}$CXCR- $-{ }^{+}$cells were not mobilized in the effectively regenerating wild-type animals, although we cannot exclude that here the mobilization occurred earlier than $24 \mathrm{~h}$ after surgery and, therefore, was not captured in the study. Dispensability of Sca- $1^{+} \mathrm{CXCR}-4^{+}$progenitors in blood flow restoration is in line with the results of the REGENT clinical trial, where intracoronary infusion of CD $34{ }^{+} \mathrm{CXCR}-4^{+}$cells (analogs of Sca- $1^{+} \mathrm{CXCR}-4^{+}$in mice) gave similar results as unselected bone marrow cells (63).

Interestingly, BMDCs seeded on Matrigel form capillarylike structures spontaneously, such as endothelial colonyforming cells (4) or late EPC (47), despite their phenotype resembling early EPC (47). This indicates that the cell phenotype is of secondary importance, and the regenerative potency of progenitors should be assessed in functional tests.

Our in vitro experiments reveal that $\mathrm{HO}-1$ is necessary for proper activity of BMDCs. As expected (7, 51, 61), HO-1deficient BMDCs are less viable when exposed to oxidants or after transplantation into the wound bed. They also display a weaker proliferation and migration either in control conditions or in response to growth factors. Similar effects were observed in murine mature or progenitor endothelial cells $(13,28)$ and in human endothelium with less active variants of Hmoxl promoter (61). We also demonstrated a weaker angiogenic potency of $\mathrm{HO}-1^{-/}$BMDCs in capillary sprouting assay, confirming the results obtained earlier in human endothelial cells treated with HO-1 inhibitors (28) or in murine endothelial cells isolated from $\mathrm{HO}-1^{+/+}$or HO- $1^{-/-}$mice (13).

Reduced levels of HO-1 in $\mathrm{HO}-1^{+/-}$BMDCs cultured under normoglycemic conditions did not significantly affect cell viability, proliferation, and migration, but impaired angiogenic potential (summarized in Fig. 8). We observed such a limited effect of HO-1 haploinsufficiency in earlier experiments, where wound healing was strongly delayed in HO- $1^{-/-}$animals. In 3-month-old HO- $1^{+/-}$mice, this process was almost as efficient as in their wild-type counterparts. In older $\mathrm{HO}-1^{+/-}$individuals, however, the wound healing was significantly delayed (22). In current experiments, we found that hyperglycemia, in addition, reduced migratory capacities of the HO- $1^{+/-}$BMDCs. Our in vitro experiments also indicate that hyperglycemia does not impair the formation of capillaries by BMDCs but significantly attenuates paracrine stimulation of endothelial cells.

In our hands, BMDC transplantation did not influence tissue regeneration (in a wound-healing model) or caused even deleterious effects (in hind limb ischemia model). Why an injection of BMDCs impaired blood flow recovery is not clear. We cannot exclude the fact that cells formed aggregates which occluded small blood vessels. We injected, however, only $0.5 \times 10^{6}$ cells, whereas $2 \times 10^{6}$ cells were used in some earlier experiments (10). Moreover, transplantation of $10^{5}-10^{6}$ of the cells in murine models investigating therapeutic vascularization seems to be justified as a safe number 


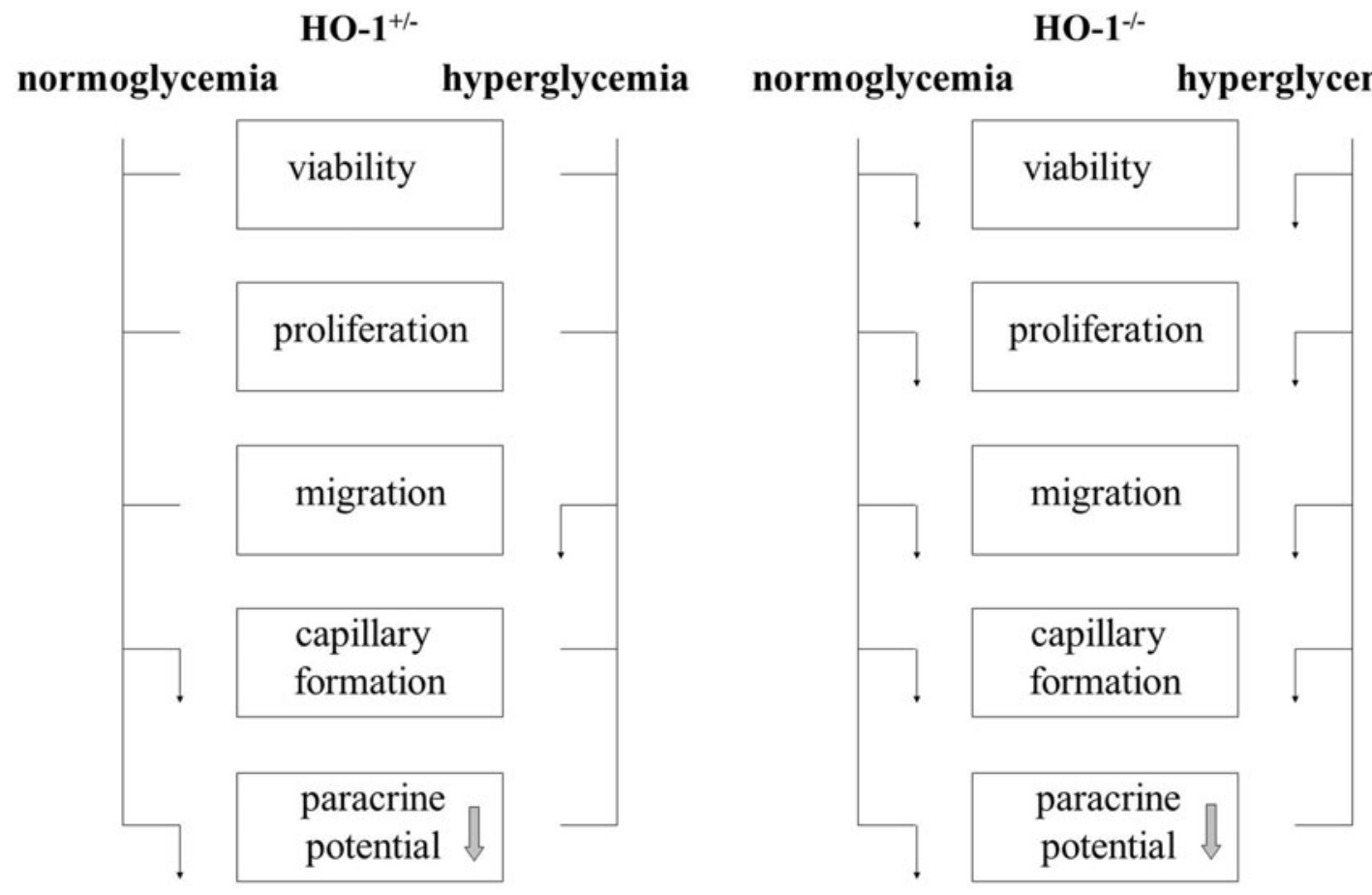

FIG. 8. Influence of HO-1 haploinsufficiency $\left(\mathrm{HO}^{+/-}\right)^{+-}$and HO-1 deficiency $\left(\mathrm{HO}^{-1} \mathrm{1}^{-/}\right)$on BMDCs cultured in normoglycemia and hyperglycemia. $\downarrow$, inhibition; - , no effect. Paracrine potential is reduced by hyperglycemia regardless of HO-1 genotype (indicated by arrow in the box).

of the cells that are able to promote re-endothelialization/ neovascularization $(25,29,32,69,72)$. The second possibility is that an injection of BMDCs, which contain monocyte-like cells, might lead to an increased inflammatory reaction. In case of the wound-healing model, lack of effect of BMDC injection on tissue regeneration might be related to the very fast clearance of these cells from the skin $(\sim 70 \%$ after $6 \mathrm{~h}, \sim 95 \%$ after 3 days, and $\sim 99.5 \%$ after 7 days). A small number of $\mathrm{HO}-1^{+/+}$BMDCs can be recognized in the sections from the wounds 2 weeks after the injection, whereas HO- $1^{-1-}$ cells are almost lacking. Mobilization of the endogenous BMDCs might have also overridden the activity of exogenously administered cells. However, a similar situation may occur in patients in whom such an approach might be tested; hence, we believe that the observations provided here are of relevance for clinical conditions.

Since postnatal neovascularization is mostly regulated by paracrine signals (5), we employed a cell-free strategy for the stimulation of blood flow recovery in ischemic limbs. Such an approach may have two advantages: It is safer than an injection of cells (what applies all the more so to cells transduced ex vivo with viral vectors), and it avoids the problem of a large number of cells that are needed to be injected into a patient. Applications of proangiogenic growth factor cocktails produced ex vivo by the cells have been already carried out with positive effects $(5,15,35,37,56,64)$. Clinical trials with regard to monotherapy with proangiogenic proteins were not satisfying (21), and possibly a synergistic action of growth factors is needed for the formation of stable blood vessels (15). Our experiments show that an injection of conditioned media harvested from BMDCs accelerates the blood flow recovery in ischemic muscles of diabetic HO- $1^{+/-}$mice. The therapeutic effect is clear for media harvested from both $\mathrm{HO}-1^{+/+}$and $\mathrm{HO}-1^{-/-} \mathrm{BMDCs}$; however, those from $\mathrm{HO}-1^{-1-}$ cells tended to be less efficient. A limitation of this study is a lack of a precise phenotypic characterization of cell population(s) in heterogeneous BMDC cultures, which are responsible for this beneficial effect. Nevertheless, the protocol used enables obtaining heterogeneous but reproducible cell cultures. We suppose that augmented angiogenesis not only results from a direct stimulation of blood vessel formation by growth factors present in conditioned media, but is also accompanied by induction of proangiogenic genes at the site of the injection. Improved blood flow recovery might be also related to the vasodilatory effect of HO-1-derived CO; however, we did not observe a significant difference in control limb perfusion between $\mathrm{HO}-1^{+/+}$and $\mathrm{HO}-1^{-/-}$hyperglycemic mice, which suggests that this mechanism does not play a crucial role here.

In summary, we demonstrated that HO-1 is necessary for proper proangiogenic function of BMDCs. Interestingly, angiogenic potential is also impaired in $\mathrm{HO}-1$ haploinsufficient BMDCs. A low level of HO-1 in hyperglycemic mice leads to worse blood flow recovery in ischemic muscle, which can be rescued by an injection of conditioned media from cultured BMDCs, especially from cells with a higher expression of $\mathrm{HO}-1$.

\section{Materials and Methods}

For a more detailed description of methods, please see the "Supplementary Materials and Methods" section. 
Animals

$\mathrm{HO}-1^{-/-}$mice, $\mathrm{HO}-1^{+/-}$mice, and $\mathrm{HO}-1^{+/+}$littermates (C57BL/6 $\times$ FVB background, 12-week-old males) were used for all the experiments, except an analysis of EPC in bone marrow, where 1-year-old animals were employed.

\section{Flow cytometric detection of EPC in bone marrow}

Bone marrow cells were collected from tibias and femurs of adult mice, stained in PBS with $2 \%$ FBS for 20 min on ice with proper antibodies, and analyzed using an LRS II flow cytometer (BD).

\section{BMDCs isolation and culture}

Total bone marrow cells were flashed from tibias and femurs of $\mathrm{HO}-1^{+/+}, \mathrm{HO}-1^{+/-}$, and $\mathrm{HO}-1^{-/-}$mice and centrifuged on Ficoll gradient (400 g, 45 min, room temperature). Buffy coat cells were washed thrice with PBS and seeded on fibronectin $(20 \mu \mathrm{g} / \mathrm{ml})$ and gelatin $(0.25 \%)$-coated dishes in EGM-2 MV media (EBM-2 with supplement) containing $10 \%$ FBS and $5 \mathrm{~m} M$ glucose (LG) or $33 \mathrm{mM}$ glucose $(\mathrm{HG})$. All experiments were performed in cultures at a confluence of $90 \%, 7-10$ days after isolation, except the measurement of proliferation, where cell confluence was $50 \%$. Some cells were incubated for the last $24 \mathrm{~h}$ under hypoxic conditions $\left(2 \% \mathrm{O}_{2}, 5 \% \mathrm{CO}_{2}, \mathrm{LG}\right)$. To analyze the acLDL uptake and BS1 binding, the cells were incubated for $2 \mathrm{~h}$ in the presence of acLDL-DiI $(20 \mu \mathrm{g} / \mathrm{ml})$ or BS1-FITC $(10 \mu \mathrm{g} / \mathrm{ml})$ and then inspected under a fluorescence microscope (Nikon Eclipse TX-100).

\section{HAECs culture}

Cells were cultured in EGM-2 MV complete medium.

\section{RNA isolation}

RNA was isolated from tissues or cultured cells using a modified acid guanidinium thiocyanate-phenol-chloroform extraction method, precipitated in isopropanol, washed in ethanol, dissolved in water, and stored at $-80^{\circ} \mathrm{C}$.

\section{Transcriptome analysis}

Transcriptome of cultured BMDCs was analyzed using Agilent Whole Mouse Genome Oligo microarrays with binding sites for 44,000 sequences.

\section{Detection of apoptosis}

Cells were washed with PBS, stained with Hoechst 33342 and 7AAD according to the protocol by (59), and analyzed using an LRS II flow cytometer (BD).

\section{Detection of proliferation}

Proliferating cells were analyzed using flow cytometry after a Hoechst/pyronin Y staining.

\section{Migration assay}

Migration was measured using QCM Cell Migration Assay with inserts of a diameter of $8 \mu \mathrm{m}$ (Chemicon).

\section{Tube formation on Matrigel}

Formation of tubes by HAECs was assayed using growth factor-reduced Matrigel in 96-well plates.

\section{Spheroid culture assay}

Spheroid culture assay was performed as previously described (68).

\section{Cell therapy of wounds and ischemic limbs with BMDCs}

For the wound-healing experiment, BMDCs isolated from HO- $1^{+/+}$or HO- $1^{-/-}$mice were stained with PKH67. Two full-thickness excisional wounds were generated on either side of the dorsal midline of each mouse. Immediately after injury, 900,000 viable $\mathrm{HO}-1^{+/+}$or $\mathrm{HO}-1^{-/-}$cells or PBS were injected intradermally into four places around the wound.

For the hind limb ischemia experiment, $\mathrm{HO}-1^{+/+}$or HO- $1^{-/-}$mice were subjected to femoral artery ligation (49). $\mathrm{PBS}$ or $500,000 \mathrm{BMDC}$ isolated from $\mathrm{HO}-1^{+1+}$ or $\mathrm{HO}-1^{-1-}$ individuals were injected intravenously next day after the surgery.

\section{Cell survival in vivo}

Cell survival in vivo was determined after the transplantation of viable cultured BMDCs that were isolated from HO- $1^{+/+}$or HO- $1^{-/-}$male mice into the tail vein $(500,000$ cells/animal) or into healthy skin $(200,000$ cells/animal) of HO- $1^{+/+}$female mice. The number of cells was quantified by detecting the male sry gene.

\section{Induction of hyperglycemia}

Hyperglycemia was induced by an intraperitoneal injection of STZ ( $50 \mathrm{mg} / \mathrm{kg}$ of body weight) for 5 consecutive days in $\mathrm{HO}-1^{+/-}$and $\mathrm{HO}-1^{+/+}$mice. Individuals were regarded as hyperglycemic when fasting blood glucose level exceeded $240 \mathrm{mg} / \mathrm{dl}(31)$.

\section{Gene expression analysis in caput gastrocnemius muscle}

Total cellular RNA was isolated from caput gastrocnemius muscle and reversely transcribed. Gene expression at the mRNA levels was checked by real-time PCR. Total protein was isolated from caput gastrocnemius muscle. HO-1 expression at the protein level was checked by ELISA.

\section{Hind limb ischemia in normoglycemic and hyperglycemic mice}

Four weeks after STZ injections, normoglycemic and hyperglycemic mice were anesthetized and subjected to left femoral artery ligation to induce limb ischemia. The superficial blood flow of the ischemic and contralateral limbs was measured at day 0, 7, and 28 using a Laser Doppler Perfusion Imager System (PIM II; Perimed).

\section{Progenitor cell mobilization}

Peripheral blood was harvested from vena cava superior. Cells were stained with proper antibodies and analyzed using an LSRII cytometer (BD). 


\section{Cell-free therapy of ischemic limbs}

BMDCs from $\mathrm{HO}-1^{+/+}$or $\mathrm{HO}-1^{-/-}$mice were incubated in EBM-2 containing $0.5 \%$ FBS for $24 \mathrm{~h}$. After this period, conditioned media were collected. HO- ${ }^{+/-}$STZ-treated mice $(n=12)$ were subjected to femoral artery ligation. Conditioned or control (EBM-2 with $0.5 \%$ FBS) media in a total volume of $30 \mu \mathrm{l}$ were injected intramuscularly into $\mathrm{ca}$ put gastrocnemius muscle at days 0,1 , and 2 . Blood flow measurements and necrotic toe assessments were done at days 0,3 , and 7 .

\section{CD31 immunohistochemical staining}

Gastrocnemius muscles were excised, embedded in OCT compound (Tissue-Tek), and snap frozen in liquid nitrogen. Cryostat sections were stained for CD31 to assess capillary density.

\section{Statistical analysis}

Results are expressed as mean \pm SEM. In vitro experiments were repeated at least thrice, while in vivo studies were performed in six mice per group, unless otherwise indicated. In the transcriptome study, the results were analyzed using one-tailed Bayesian ANOVA with post hoc Tukey HSD test, followed by $p$ correction with Benjamini-Hochberg FDR test, at FDR $<20 \%$. In the other experiments, the two-tailed Student's $t$-test was used for a comparison of the groups and the two-tailed Fisher's exact test was used for a comparison of proportions.

\section{Acknowledgments}

The authors thank Ewa Zuba-Surma for technical help with some flow cytometry analyses. They truly appreciate the technical assistance of Agnieszka Andrychowicz-Rog, Aleksandra Bartelik, and Janusz Drebot. They are grateful to Anupam Agarwal, University of Alabama of Birmingham, for providing the $\mathrm{HO}-1^{+/-}$breeding pairs. This work was supported by European Union Framework Programs POIG 01.01.02-00-109/09 and 01.02.00-069/09 and by National Science Center grant N N301 460938. They also used the equipment obtained from EU Framework Programs POIG 02.01.00-12-064/08 and 02.02.00-00-014/08 (to Faculty of Biochemistry, Biophysics and Biotechnology). A.G.-P. is a recipient of L'Oreal Poland for Women in Science Scholarship and START Scholarship of Foundation for Polish Science (FNP). A.L. is the recipient of the POMOST grant from FNP, and Agnieszka Jazwa is the recipient of the HOMING Plus grant. Alicja Jozkowicz was an ISRF fellow supported by The Wellcome Trust. J.D. and Alicja Jozkowicz participated in the COST Action HypoxiaNet TD0901.

\section{Author Disclosure Statement}

The authors have no conflicting financial interests.

\section{References}

1. Adaikalakoteswari A, Balasubramanyam M, Rema M, and Mohan V. Differential gene expression of NADPH oxidase (p22phox) and hemoxygenase-1 in patients with Type 2 diabetes and microangiopathy. Diabet Med 23: 666-674, 2006.
2. Asahara T, Masuda H, Takahashi T, Kalka C, Pastore C, Silver M, Kearne M, Magner M, and Isner JM. Bone marrow origin of endothelial progenitor cells responsible for postnatal vasculogenesis in physiological and pathological neovascularization. Circ Res 85: 221-228, 1999.

3. Bachelder RE, Crago A, Chung J, Wendt MA, Shaw LM, Robinson G, and Mercurio AM. Vascular endothelial growth factor is an autocrine survival factor for neuropilinexpressing breast carcinoma cells. Cancer Res 61: 57365740, 2001.

4. Baker CD, Ryan SL, Ingram DA, Seedorf GJ, Abman SH, and Balasubramaniam V. Endothelial colony-forming cells from preterm infants are increased and more susceptible to hyperoxia. Am J Respir Crit Care Med 180: 454-461, 2009.

5. Barcelos LS, Duplaa C, Krankel N, Graiani G, Invernici G, Katare R, Siragusa M, Meloni M, Campesi I, Monica M, Simm A, Campagnolo P, Mangialardi G, Stevanato L, Alessandri G, Emanueli C, and Madeddu P. Human CD133 + progenitor cells promote the healing of diabetic ischemic ulcers by paracrine stimulation of angiogenesis and activation of Wnt signaling. Circ Res 104: 1095-1102, 2009.

6. Bhang SH, Kim JH, Yang HS, La WG, Lee TJ, Kim GH, Kim HA, Lee M, and Kim BS. Combined gene therapy with hypoxia-inducible factor-1alpha and heme oxygenase-1 for therapeutic angiogenesis. Tissue Eng Part A 17: 915926, 2011.

7. Brouard S, Otterbein LE, Anrather J, Tobiasch E, Bach FH, Choi AM, and Soares MP. Carbon monoxide generated by heme oxygenase 1 suppresses endothelial cell apoptosis. $J$ Exp Med 192: 1015-1026, 2000.

8. Bruce CR, Carey AL, Hawley JA, and Febbraio MA. Intramuscular heat shock protein 72 and heme oxygenase-1 mRNA are reduced in patients with type 2 diabetes: evidence that insulin resistance is associated with a disturbed antioxidant defense mechanism. Diabetes 52: 2338-2345, 2003.

9. Caporali A, Meloni M, Vollenkle C, Bonci D, Sala-Newby GB, Addis R, Spinetti G, Losa S, Masson R, Baker AH, Agami R, le Sage C, Condorelli G, Madeddu P, Martelli F, and Emanueli C. Deregulation of microRNA-503 contributes to diabetes mellitus-induced impairment of endothelial function and reparative angiogenesis after limb ischemia. Circulation 123: 282-291, 2011.

10. Carmona G, Chavakis E, Koehl U, Zeiher AM, and Dimmeler S. Activation of Epac stimulates integrin-dependent homing of progenitor cells. Blood 111: 2640-2646, 2008.

11. Chen YH, Lin SJ, Lin MW, Tsai HL, Kuo SS, Chen JW, Charng MJ, Wu TC, Chen LC, Ding YA, Pan WH, Jou YS, and Chau LY. Microsatellite polymorphism in promoter of heme oxygenase-1 gene is associated with susceptibility to coronary artery disease in type 2 diabetic patients. Hum Genet 111: 1-8, 2002.

12. da Silva JL, Stoltz RA, Dunn MW, Abraham NG, and Shibahara S. Diminished heme oxygenase-1 mRNA expression in RPE cells from diabetic donors as quantitated by competitive RT/PCR. Curr Eye Res 16: 380-386, 1997.

13. Deshane J, Chen S, Caballero S, Grochot-Przeczek A, Was H, Li Calzi S, Lach R, Hock TD, Chen B, Hill-Kapturczak N, Siegal GP, Dulak J, Jozkowicz A, Grant MB, and Agarwal A. Stromal cell-derived factor 1 promotes angiogenesis via a heme oxygenase 1-dependent mechanism. $J$ Exp Med 204: 605-618, 2007.

14. Di Filippo C, Marfella R, Cuzzocrea S, Piegari E, Petronella P, Giugliano D, Rossi F, and D'Amico M. Hyperglycemia in streptozotocin-induced diabetic rat 
increases infarct size associated with low levels of myocardial HO-1 during ischemia/reperfusion. Diabetes 54: 803-810, 2005.

15. Di Santo S, Yang Z, Wyler von Ballmoos M, Voelzmann J, Diehm N, Baumgartner I, and Kalka C. Novel cell-free strategy for therapeutic angiogenesis: in vitro generated conditioned medium can replace progenitor cell transplantation. PLoS One 4: e5643, 2009.

16. Dick P, Schillinger M, Minar E, Mlekusch W, Amighi J, Sabeti S, Schlager O, Raith M, Endler G, Mannhalter C, Wagner O, and Exner M. Haem oxygenase-1 genotype and cardiovascular adverse events in patients with peripheral artery disease. Eur J Clin Invest 35: 731-737, 2005.

17. Dulak J, Deshane J, Jozkowicz A, and Agarwal A. Heme oxygenase-1 and carbon monoxide in vascular pathobiology: focus on angiogenesis. Circulation 117: 231-241, 2008.

18. Exner M, Minar E, Wagner O, and Schillinger M. The role of heme oxygenase-1 promoter polymorphisms in human disease. Free Radic Biol Med 37: 1097-1104, 2004.

19. Fadini GP, Losordo D, and Dimmeler S. Critical reevaluation of endothelial progenitor cell phenotypes for therapeutic and diagnostic use. Circ Res 110: 624-637, 2012.

20. Grochot-Przeczek A, Dulak J, and Jozkowicz A. Haem oxygenase-1: non-canonical roles in physiology and pathology. Clin Sci (Lond) 122: 93-103, 2012.

21. Grochot-Przeczek A, Dulak J, and Jozkowicz A. Therapeutic angiogenesis for revascularization in peripheral artery disease. Gene 525: 220-228, 2013.

22. Grochot-Przeczek A, Lach R, Mis J, Skrzypek K, Gozdecka M, Sroczynska P, Dubiel M, Rutkowski A, Kozakowska M, Zagorska A, Walczynski J, Was H, Kotlinowski J, Drukala J, Kurowski K, Kieda C, Herault Y, Dulak J, and Jozkowicz A. Heme oxygenase-1 accelerates cutaneous wound healing in mice. PLoS One 4: e5803, 2009.

23. Gulesserian T, Wenzel C, Endler G, Sunder-Plassmann R, Marsik C, Mannhalter C, Iordanova N, Gyongyosi M, Wojta J, Mustafa S, Wagner O, and Huber K. Clinical restenosis after coronary stent implantation is associated with the heme oxygenase- 1 gene promoter polymorphism and the heme oxygenase-1 +99G/C variant. Clin Chem 51: 1661-1665, 2005.

24. Hur J, Yoon CH, Kim HS, Choi JH, Kang HJ, Hwang KK, $\mathrm{Oh} \mathrm{BH}$, Lee MM, and Park YB. Characterization of two types of endothelial progenitor cells and their different contributions to neovasculogenesis. Arterioscler Thromb Vasc Biol 24: 288-293, 2004.

25. Iwaguro H, Yamaguchi J, Kalka C, Murasawa S, Masuda H, Hayashi S, Silver M, Li T, Isner JM, and Asahara T. Endothelial progenitor cell vascular endothelial growth factor gene transfer for vascular regeneration. Circulation 105: 732-738, 2002.

26. Jazwa A, Stepniewski J, Zamykal M, Jagodzinska J, Meloni M, Emanueli C, Jozkowicz A, and Dulak J. Pre-emptive hypoxia-regulated HO-1 gene therapy improves postischaemic limb perfusion and tissue regeneration in mice. Cardiovasc Res 97: 115-124, 2012.

27. Jiang Y, Chen L, Tang Y, Ma G, Shen C, Qi C, Zhu Q, Yao $\mathrm{Y}$, and Liu N. HO-1 gene overexpression enhances the beneficial effects of superparamagnetic iron oxide labeled bone marrow stromal cells transplantation in swine hearts underwent ischemia/reperfusion: an MRI study. Basic Res Cardiol 105: 431-442, 2010.

28. Jozkowicz A, Huk I, Nigisch A, Weigel G, Dietrich W, Motterlini R, and Dulak J. Heme oxygenase and angiogenic activity of endothelial cells: stimulation by carbon monoxide and inhibition by tin protoporphyrin-IX. Antioxid Redox Signal 5: 155-162, 2003.

29. Kalka C, Masuda H, Takahashi T, Kalka-Moll WM, Silver M, Kearney M, Li T, Isner JM, and Asahara T. Transplantation of ex vivo expanded endothelial progenitor cells for therapeutic neovascularization. Proc Natl Acad Sci U S A 97: 3422-3427, 2000.

30. Kawamoto A, Katayama M, Handa N, Kinoshita M, Takano H, Horii M, Sadamoto K, Yokoyama A, Yamanaka T, Onodera R, Kuroda A, Baba R, Kaneko Y, Tsukie T, Kurimoto Y, Okada Y, Kihara Y, Morioka S, Fukushima $\mathrm{M}$, and Asahara T. Intramuscular transplantation of G-CSFmobilized CD34 $(+)$ cells in patients with critical limb ischemia: a phase I/IIa, multicenter, single-blinded, doseescalation clinical trial. Stem Cells 27: 2857-2864, 2009.

31. Keren P, George J, Shaish A, Levkovitz H, Janakovic Z, Afek A, Goldberg I, Kopolovic J, Keren G, and Harats D. Effect of hyperglycemia and hyperlipidemia on atherosclerosis in LDL receptor-deficient mice: establishment of a combined model and association with heat shock protein 65 immunity. Diabetes 49: 1064-1069, 2000.

32. Krankel N, Katare RG, Siragusa M, Barcelos LS, Campagnolo P, Mangialardi G, Fortunato O, Spinetti G, Tran N, Zacharowski K, Wojakowski W, Mroz I, Herman A, Manning Fox JE, MacDonald PE, Schanstra JP, Bascands JL, Ascione R, Angelini G, Emanueli C, and Madeddu P. Role of kinin B2 receptor signaling in the recruitment of circulating progenitor cells with neovascularization potential. Circ Res 103: 1335-1343, 2008.

33. Lara-Hernandez R, Lozano-Vilardell P, Blanes P, Torreguitart-Mirada N, Galmes A, and Besalduch J. Safety and efficacy of therapeutic angiogenesis as a novel treatment in patients with critical limb ischemia. Ann Vasc Surg 24: 287-294, 2010.

34. Lassaletta AD, Chu LM, and Sellke FW. Therapeutic neovascularization for coronary disease: current state and future prospects. Basic Res Cardiol 106: 897-909, 2011.

35. Lee MJ, Kim J, Lee KI, Shin JM, Chae JI, and Chung HM. Enhancement of wound healing by secretory factors of endothelial precursor cells derived from human embryonic stem cells. Cytotherapy 13: 165-178, 2011.

36. Leturque A, Brot-Laroche E, and Le Gall M. GLUT2 mutations, translocation, and receptor function in diet sugar managing. Am J Physiol Endocrinol Metab 296: E985E992, 2009.

37. Li H, Zuo S, He Z, Yang Y, Pasha Z, Wang Y, and Xu M. Paracrine factors released by GATA-4 overexpressed mesenchymal stem cells increase angiogenesis and cell survival. Am J Physiol Heart Circ Physiol 299: H1772H1781, 2010.

38. Lin $\mathrm{HH}$, Chen $\mathrm{YH}$, Yet SF, and Chau LY. After vascular injury, heme oxygenase-1/carbon monoxide enhances reendothelialization via promoting mobilization of circulating endothelial progenitor cells. J Thromb Haemost 7: 1401-1408, 2009.

39. Liu X, Wei J, Peng DH, Layne MD, and Yet SF. Absence of heme oxygenase-1 exacerbates myocardial ischemia/ reperfusion injury in diabetic mice. Diabetes 54: 778-784, 2005.

40. Loboda A, Jazwa A, Grochot-Przeczek A, Rutkowski AJ, Cisowski J, Agarwal A, Jozkowicz A, and Dulak J. Heme oxygenase-1 and the vascular bed: from molecular mechanisms to therapeutic opportunities. Antioxid Redox Signal 10: 1767-1812, 2008. 
41. Long J, Wang S, Zhang Y, Liu X, and Zhang $H$. The therapeutic effect of vascular endothelial growth factor gene- or heme oxygenase-1 gene-modified endothelial progenitor cells on neovascularization of rat hindlimb ischemia model. J Vasc Surg 58: 756-765.e2, 2013.

42. Loomans CJ, De Koning EJ, Staal FJ, Rabelink TJ, and Zonneveld AJ. Endothelial progenitor cell dysfunction in type 1 diabetes: another consequence of oxidative stress? Antioxid Redox Signal 7: 1468-1475, 2005.

43. Lublinghoff N, Winkler K, Winkelmann BR, Seelhorst U, Wellnitz B, Boehm BO, Marz W, and Hoffmann MM. Genetic variants of the promoter of the heme oxygenase-1 gene and their influence on cardiovascular disease (the Ludwigshafen Risk and Cardiovascular Health study). BMC Med Genet 10: 36, 2009.

44. Maines MD. The heme oxygenase system: a regulator of second messenger gases. Annu Rev Pharmacol Toxicol 37: 517-554, 1997.

45. Mirotsou M, Jayawardena TM, Schmeckpeper J, Gnecchi $\mathrm{M}$, and Dzau VJ. Paracrine mechanisms of stem cell reparative and regenerative actions in the heart. $\mathrm{J} \mathrm{Mol} \mathrm{Cell}$ Cardiol 50: 280-289, 2011.

46. Moreira TJ, Cebere A, Cebers G, Ostenson CG, Efendic S, and Liljequist S. Reduced HO-1 protein expression is associated with more severe neurodegeneration after transient ischemia induced by cortical compression in diabetic Goto-Kakizaki rats. J Cereb Blood Flow Metab 27: 1710-1723, 2007.

47. Mukai N, Akahori T, Komaki M, Li Q, Kanayasu-Toyoda T, Ishii-Watabe A, Kobayashi A, Yamaguchi T, Abe M, Amagasa T, and Morita I. A comparison of the tube forming potentials of early and late endothelial progenitor cells. Exp Cell Res 314: 430-440, 2008.

48. Nath KA. Heme oxygenase-1: a provenance for cytoprotective pathways in the kidney and other tissues. Kidney Int 70: 432-443, 2006.

49. Niiyama H, Huang NF, Rollins MD, and Cooke JP. Murine model of hindlimb ischemia. J Vis Exp 2009. DOI: 10.3791/1035.

50. Nowak WN, Borys S, Kusinska K, Bukowska-Strakova K, Witek P, Koblik T, Jozkowicz A, Malecki T, and Dulak J. Number of circulating pro-angiogenic cells, growth factor and anti-oxidative gene profiles might be altered in type 2 diabetes with and without diabetic foot syndrome. $J$ Diabetes Investig 2013 [Epub ahead of print]; DOI: 10.1111/jdi.12131.

51. Otterbein LE, Bach FH, Alam J, Soares M, Tao Lu H, Wysk M, Davis RJ, Flavell RA, and Choi AM. Carbon monoxide has anti-inflammatory effects involving the mitogenactivated protein kinase pathway. Nat Med 6: 422-428, 2000.

52. Park K, Itoh H, Yamahara K, Sone M, Miyashita K, Oyamada N, Sawada N, Taura D, Inuzuka M, Sonoyama T, Tsujimoto H, Fukunaga Y, Tamura N, and Nakao K. Therapeutic potential of atrial natriuretic peptide administration on peripheral arterial diseases. Endocrinology 149: 483-491, 2008.

53. Pearson JD. Endothelial progenitor cells-an evolving story. Microvasc Res 79: 162-168, 2010.

54. Platt JL and Nath KA. Heme oxygenase: protective gene or Trojan horse. Nat Med 4: 1364-1365, 1998.

55. Radhakrishnan N, Yadav SP, Sachdeva A, Pruthi PK, Sawhney S, Piplani T, Wada T, and Yachie A. Human heme oxygenase-1 deficiency presenting with hemolysis, nephritis, and asplenia. J Pediatr Hematol Oncol 33: 7478, 2011.

56. Sahoo S, Klychko E, Thorne T, Misener S, Schultz KM, Millay M, Ito A, Liu T, Kamide C, Agrawal H, Perlman H,
Qin G, Kishore R, and Losordo DW. Exosomes from human $\mathrm{CD} 34(+)$ stem cells mediate their proangiogenic paracrine activity. Circ Res 109: 724-728, 2011.

57. Sambuceti G, Morbelli S, Vanella L, Kusmic C, Marini C, Massollo M, Augeri C, Corselli M, Ghersi C, Chiavarina B, Rodella LF, L'Abbate A, Drummond G, Abraham NG, and Frassoni F. Diabetes impairs the vascular recruitment of normal stem cells by oxidant damage, reversed by increases in pAMPK, heme oxygenase-1, and adiponectin. Stem Cells 27: 399-407, 2009.

58. Schillinger $\mathrm{M}$, Exner $\mathrm{M}$, Mlekusch $\mathrm{W}$, Domanovits $\mathrm{H}$, Huber K, Mannhalter C, Wagner O, and Minar E. Heme oxygenase- 1 gene promoter polymorphism is associated with abdominal aortic aneurysm. Thromb Res 106: 131-136, 2002.

59. Schmid I, Uittenbogaart C, and Jamieson BD. Live-cell assay for detection of apoptosis by dual-laser flow cytometry using Hoechst 33342 and 7-amino-actinomycin D. Nat Protoc 2: 187-190, 2007.

60. Suzuki M, Iso-o N, Takeshita S, Tsukamoto K, Mori I, Sato T, Ohno M, Nagai R, and Ishizaka N. Facilitated angiogenesis induced by heme oxygenase- 1 gene transfer in a rat model of hindlimb ischemia. Biochem Biophys Res Commun 302: 138-143, 2003.

61. Taha H, Skrzypek K, Guevara I, Nigisch A, Mustafa S, Grochot-Przeczek A, Ferdek P, Was H, Kotlinowski J, Kozakowska M, Balcerczyk A, Muchova L, Vitek L, Weigel G, Dulak J, and Jozkowicz A. Role of heme oxygenase-1 in human endothelial cells: lesson from the promoter allelic variants. Arterioscler Thromb Vasc Biol 30: 1634-1641, 2010.

62. Tateishi-Yuyama E, Matsubara H, Murohara T, Ikeda U, Shintani S, Masaki H, Amano K, Kishimoto Y, Yoshimoto K, Akashi H, Shimada K, Iwasaka T, and Imaizumi T. Therapeutic angiogenesis for patients with limb ischaemia by autologous transplantation of bone-marrow cells: a pilot study and a randomised controlled trial. Lancet 360: 427435, 2002.

63. Tendera M, Wojakowski W, Ruzyllo W, Chojnowska L, Kepka C, Tracz W, Musialek P, Piwowarska W, Nessler J, Buszman P, Grajek S, Breborowicz P, Majka M, and Ratajczak MZ. Intracoronary infusion of bone marrowderived selected CD34 + CXCR4 + cells and non-selected mononuclear cells in patients with acute STEMI and reduced left ventricular ejection fraction: results of randomized, multicentre Myocardial Regeneration by Intracoronary Infusion of Selected Population of Stem Cells in Acute Myocardial Infarction (REGENT) Trial. Eur Heart J 30: 1313-1321, 2009.

64. Timmers L, Lim SK, Hoefer IE, Arslan F, Lai RC, van Oorschot AA, Goumans MJ, Strijder C, Sze SK, Choo A, Piek JJ, Doevendans PA, Pasterkamp G, and de Kleijn DP. Human mesenchymal stem cell-conditioned medium improves cardiac function following myocardial infarction. Stem Cell Res 6: 206-214, 2011.

65. Tongers J, Knapp JM, Korf M, Kempf T, Limbourg A, Limbourg FP, Li Z, Fraccarollo D, Bauersachs J, Han X, Drexler H, Fiedler B, and Wollert KC. Haeme oxygenase promotes progenitor cell mobilization, neovascularization, and functional recovery after critical hindlimb ischaemia in mice. Cardiovasc Res 78: 294-300, 2008.

66. Urbich $\mathrm{C}$ and Dimmeler S. Risk factors for coronary artery disease, circulating endothelial progenitor cells, and the role of HMG-CoA reductase inhibitors. Kidney Int 67: 1672-1676, 2005. 
67. Vasa M, Fichtlscherer S, Aicher A, Adler K, Urbich C, Martin H, Zeiher AM, and Dimmeler S. Number and migratory activity of circulating endothelial progenitor cells inversely correlate with risk factors for coronary artery disease. Circ Res 89: E1-E7, 2001.

68. Was H, Cichon T, Smolarczyk R, Rudnicka D, Stopa M, Chevalier C, Leger JJ, Lackowska B, Grochot A, Bojkowska K, Ratajska A, Kieda C, Szala S, Dulak J, and Jozkowicz A. Overexpression of heme oxygenase-1 in murine melanoma: increased proliferation and viability of tumor cells, decreased survival of mice. Am J Pathol 169: 2181-2198, 2006.

69. Werner N, Junk S, Laufs U, Link A, Walenta K, Bohm M, and Nickenig G. Intravenous transfusion of endothelial progenitor cells reduces neointima formation after vascular injury. Circ Res 93: e17-e24, 2003.

70. Wu BJ, Midwinter RG, Cassano C, Beck K, Wang Y, Changsiri D, Gamble JR, and Stocker R. Heme oxygenase-1 increases endothelial progenitor cells. Arterioscler Thromb Vasc Biol 29: 1537-1542, 2009.

71. Yachie A, Niida Y, Wada T, Igarashi N, Kaneda H, Toma T, Ohta K, Kasahara Y, and Koizumi S. Oxidative stress causes enhanced endothelial cell injury in human heme oxygenase-1 deficiency. J Clin Invest 103: 129-135, 1999.

72. Yamaguchi J, Kusano KF, Masuo O, Kawamoto A, Silver M, Murasawa S, Bosch-Marce M, Masuda H, Losordo DW, Isner JM, and Asahara T. Stromal cell-derived factor-1 effects on ex vivo expanded endothelial progenitor cell recruitment for ischemic neovascularization. Circulation 107: 1322-1328, 2003.

73. Zhu Z, Wilson AT, Mathahs MM, Wen F, Brown KE, Luxon BA, and Schmidt WN. Heme oxygenase-1 suppresses hepatitis $\mathrm{C}$ virus replication and increases resistance of hepatocytes to oxidant injury. Hepatology 48: 1430-1439, 2008.

Address correspondence to: Prof. Jozef Dulak Department of Medical Biotechnology Faculty of Biochemistry, Biophysics and Biotechnology Jagiellonian University Gronostajowa 7 Krakow 30-387 Poland

E-mail: jozef.dulak@uj.edu.pl
Prof. Alicja Jozkowicz. Department of Medical Biotechnology Faculty of Biochemistry, Biophysics and Biotechnology Jagiellonian University Gronostajowa 7 Krakow 30-387 Poland

E-mail: alicja.jozkowicz@uj.edu.pl

Date of first submission to ARS Central, May 10, 2013; date of final revised submission, October 20, 2013; date of acceptance, November 9, 2013.

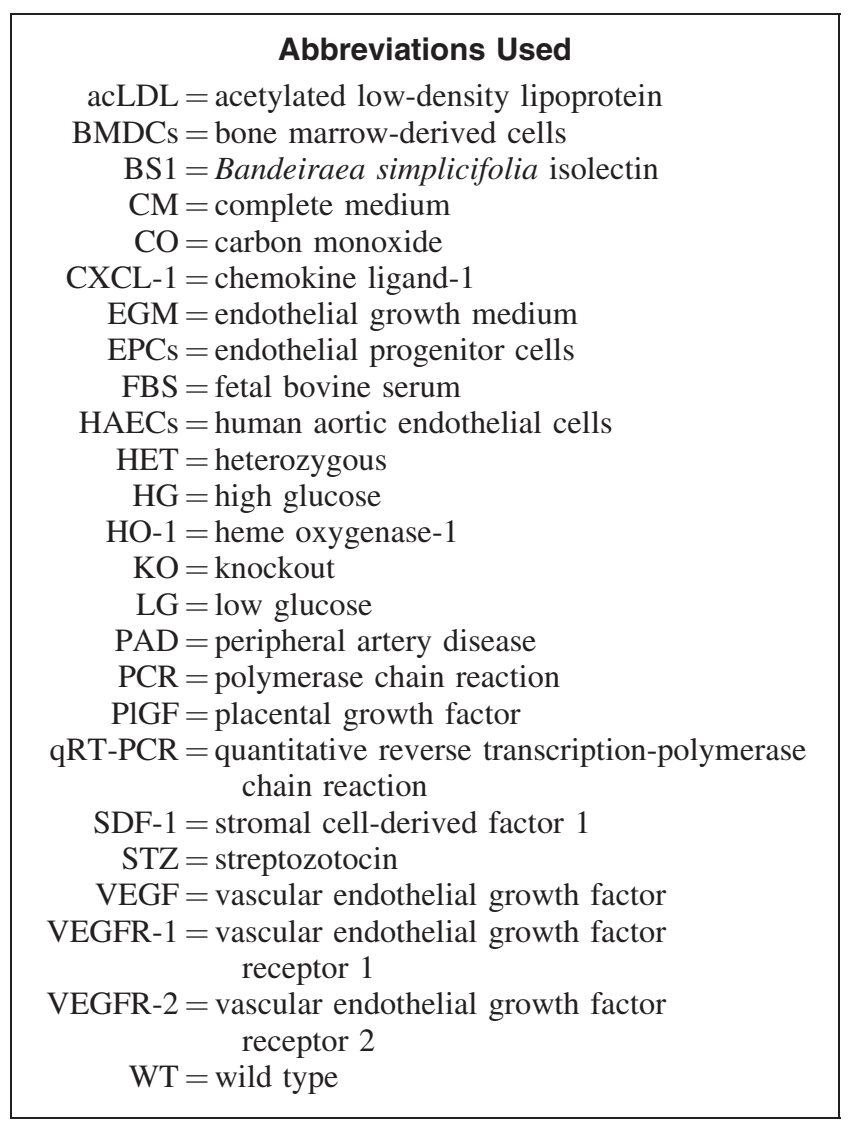

